\title{
Powdery Mildew Resistance Genes in Wheat: Identification and Genetic Analysis
}

\author{
Md. Ashraful Alam \\ College of Agronomy, Northwest A \& F University, China \\ $\&$ \\ Scientific Officer, Wheat Research Centre, BARI, Dinajpur, Bangladesh \\ E-mail: ashrafulw@yahoo.com
}

Fei Xue

College of Agronomy, Northwest A \& F University, China

Changyou Wang

College of Agronomy, Northwest A \& F University, China

Wanquan Ji (Corresponding author)

College of Agronomy, Northwest A \& F University, China

E-mail: jiwanquan2003@126.com

Received: August 12, 2011

doi:10.5539/jmbr.v1n1p20
Accepted: August 25, $2011 \quad$ Published: December 31, 2011

URL: http://dx.doi.org/10.5539/jmbr.v1n1p20

\begin{abstract}
Wheat powdery mildew, caused by Blumeria graminis f. sp. Tritici is one of the most devastating diseases of common wheat worldwide. To date, 41 loci (Pm1 to Pm45, Pm18=Pm1c, Pm22=Pm1e, Pm23=Pm4c, $P m 31=P m 21$ ) with more than 60 genes/alleles for resistance to powdery mildew have been identified and located on 18 different chromosomes in bread wheat. 29 resistance genes/alleles have been tagged with molecular markers such as restriction fragment length polymorphisms (RFLPs), random amplified polymorphic DNAs (RAPDs), amplified fragment length polymorphisms (AFLPs), sequence tagged sites (STS) and simple sequence repeats (SSRs), by using $\mathrm{F}_{2}$, back-cross populations, near-isogenic lines (NILs), doubled haploids (DH), recombinant inbred lines (RILs) or bulked segregant analysis (BSA). The detail information on chromosomal location, molecular markers linked to powdery mildew, mapping population and molecular mapping of powdery mildew resistance genes have been reviewed.
\end{abstract}

Keywords: Blumeria graminis f.sp. tritici, Molecular markers, Mapping population, Molecular mapping, Powdery mildew resistance gene, Triticum aestivum

\section{Introduction}

Wheat powdery mildew, caused by Blumeria graminis (DC.) E.O. Speer f. sp. Tritici Em. Marchal $($ Bgt $)=$ Erysiphe graminis DC. Ex Merat f. sp. Tritici Em. Marchal, is one of the most devastating diseases of common wheat occurs in many areas, including China, Germany, Japan, Russia, United Kingdom, South and West Asia, North and East Africa, and the Southeastern United States (Bennett, 1984). Yield losses ranging from 13 to $34 \%$ due to this disease (Griffey et al., 1993; Leath \& Bowen, 1989). Growing of resistant cultivars offer effective, economically sound and environmentally safe approach to eliminate the use of fungicides and reducing crop losses caused by powdery mildew. There are two types of resistance to powdery mildew. One is called monogenic (vertical) or race specific resistance, which is effective for some isolates of powdery mildew, but ineffective for others. Race specific resistance is mainly via a hypersensitive foliar reaction directly involving single major R genes, designated as Pm (powdery mildew) genes, in a gene-for-gene interaction (Bennett, 1984; 
Chen and Chelkowski, 1999; Hsam and Zeller, 2002). Race-specific resistance genes are expressed in seedlings and throughout the vegetative cycle of wheat. Though race-specific resistance have been extensively used in wheat breeding programs, selection pressure exerted by cultivars with race-specific resistance genes results in the rapid build-up of isolates with matching virulence genes. Afterward, race-specific resistance breaks down when confronted by pathogen isolates with matching virulence genes and, therefore, is ephemeral.

Another type of resistance to powdery mildew is called adult plant resistance (APR), which retards infection, growth and reproduction of the pathogen in adult plants but not in seedlings. It is also called "slow mildewing" (Shaner, 1973) and "partial resistance" (Hautea et al., 1987). This type of resistance can be identified in cultivars with defeated race-specific genes or lacking known race-specific resistance genes. APR to powdery mildew is more durable than race-specific resistance. For example, APR in wheat cultivar Knox and its derivatives remained effective against powdery mildew infection during the 20 years in which these cultivars were grown commercially (Shaner, 1973). Massey, a derivative of Knox62, was released from Virginia Tech in 1981 (Starling et al. 1984), and still has effective powdery mildew resistance in adult plants. Up to now, 41 loci (Pm1 to Pm45, $P m 18=P m 1 c, P m 22=P m 1 e, P m 23=P m 4 c, P m 31=P m 21)$ with more than 60 genes/alleles for resistance to powdery mildew have been identified and located on various chromosomes in bread wheat and its relatives (Ma et al., 2011; McIntosh et al., 2008; Luo et al., 2009; Li et al., 2009; Hua et al., 2009; He et al., 2009). However, resistances of genes are frequently overcome by new Bgt isolates, because the presence and frequency of virulence genes in the pathogen population changes continuously (Leath \& Murphy, 1985; Menzies \& MacNeil, 1986; Limpert et al. 1987; Namuco et al. 1987). The effective management strategy has been to replace cultivars when their resistance is no longer effective (Wolf, 1984; Leath \& Heun, 1990).

Molecular markers are now widely used for gene tagging, gene mapping, and other genetics research because they are not influenced by environmental conditions and growth stage. The use of PCR based molecular markers to tag genomic regions are more efficient for marker assisted selection (MAS), due to the small amount of DNA template required and easy to handling of large population sizes. The identification of molecular markers of flanking disease resistance genes, simplifies breeding activities such as cultivar development (Bonnett et al., 2005), near isogenic line development (Zhou et al., 2005), and pyramiding resistance genes into single genotypes by marker assisted selection (MAS). Many of the recently reported of $P m$ genes have associated markers (Miranda et al., 2006, 2007; Perugini et al., 2008). Recently, molecular markers such as restriction fragment length polymorphisms (RFLPs), random amplified polymorphic DNAs (RAPDs), amplified fragment length polymorphisms (AFLPs), sequence tagged sites (STS) and microsatellites, also termed simple sequence repeats (SSRs), have been widely used to tag and identify powdery mildew resistance genes in wheat by using $\mathrm{F}_{2}$ and back-cross populations, near-isogenic lines (NILs), doubled haploids (DH), recombinant inbred lines (RILs) or bulked segregant analysis (BSA, Michelmore et al., 1991).

\section{Chromosomal Location of Identified $P \boldsymbol{m}$ Genes}

In recent years, wheat genomics research has increased the use of genetic maps to position a gene of interest between close flanking markers (Haley \& Knott, 1992). The application of molecular markers in plant systems increases the efficiency of conventional plant breeding by carrying out indirect selection through molecular markers linked to the traits of interest (Gupta et al., 1999). A linkage map gives information on the position of markers within a linkage group. The map positions are inferred from estimates of recombination frequencies between markers. The distance between these markers is expressed in centimorgan (cM) which represents the recombination rates between them (Jones et al., 1997). Chromosomal positions of several mapped powdery mildew resistance gene loci are presented in Figure 1.

The presence of $P m$ resistant genes is vital not only for monogenic resistance but also the defeated $P m$ genes often confer oligogenic and quantitative type resistance when combined together (Royer et al., 1984; Pedersen \& Leath, 1988; Paillard et al., 2000). Chromosomal locations, cultivars/lines, sources and references for the 64 known powdery mildew resistance genes/alleles have been identified as major genes for vertical resistance to powdery mildew in wheat (Ma et al., 2011; McIntosh et al., 2008; Luo et al., 2009; Li et al., 2009; Hua et al., 2009; He et al., 2009) (Table 1). Thirty $P m$ alleles at 25 loci have been nominated for wheat powdery mildew resistance (McIntosh et al. 1995). Twenty-five alleles at 19 loci from $P m 1$ to $P m 19$, their locations at chromosomes, and their sources have been reviewed (McIntosh et al. 1995). Other Pm alleles such as Pm20, Pm21, and Pm22 have been reported by Friebe et al., 1994, Qi et al., 1995, and Peusha et al., 1996 and Pm25 has been identified by Shi et al. 1998. Host-pathogen interactions analysis, chromosomal (cytogenesis) analysis and molecular marker techniques have been utilized for determining chromosomal locations of $P m$ genes. These powdery mildew resistance genes are non-randomly distributed in the genome (Table 3), but form clusters in gene-rich regions (Gill et al., 1996a, b). The highest numbers of $\mathrm{Pm}$ loci are contained by each $6 \mathrm{~B}$ and $7 \mathrm{~B}$ chromosome with 5 known $\mathrm{Pm}$ loci. Chromosomes 
without known Pm genes are 3A (Pm44), 4D, and 5A (according to Hsam \& Zeller, 2002). Gene loci that contain more than one resistance allele are $P m 1$ with 4 alleles, $P m 3$ with 9 alleles, $P m 4$ with 3 alleles, $P m 5$ with 4 alleles (Chen \& Chelkowski, 1999; Hsam \& Zeller, 2002). Hsam and Zeller (2002) stated that loci Pm10, Pm11, Pm14, and Pm15 contain individual genes for resistance to Erysiphe graminis f.sp. agropyri and are not effective against Blumeria graminis f. sp. Tritici. Eight gene loci were identified in homoeologous group 1, whereas only one gene (Pm16) was found in homoeologous group 4 (i.e. chromosome 4A; Reader \& Miller, 1991).

Xue et al. (2009) reported that the Chinese landraces wheat line Xiaobaidong contained a new recessive gene, $m l x b d$ which was located on chromosome 7BL and near the locus Pm5. Powdery mildew resistance gene Mld was located on chromosome 4B in the wheat lines, Halle 13471, H8810/47 and Maris Dove. It was transferred from T. durum (McIntosh et al., 1995). Zeller et al. (1993b) reported that three wheat cultivars, Abo, Aristide and Courtot, contained a major gene, Mlar, for resistance to the German Bgt isolate no.2. Robe and Doussinault (1995) reported that the line RF714 contained a new recessive gene, mlre, for wheat powdery mildew resistance, which was derived from a cross between Aegilops squarrosa 33 and Triticum dicoccum 119. They postulated that mlre was derived from T. dicoccum. A new recessive gene, pmTD1, was identified in the wheat line NC92-8562 transferred from Ae. Tauschii ssp. Tauschii (Shi et al., 1998). Liu et al. (1989) reported that the variety Kenguia 1 contained a new gene, $K G$, for powdery mildew resistance, which was located on chromosome $6 \mathrm{~A}$.

\section{Sources and Distribution of Resistance Genes}

Common sources of $P m$ genes are different species within the primary, secondary and tertiary gene pools. Bread wheat is an allohexaploid species $(2 n=6 x=42)$, with three distinct genomes (AABBDD). Many of the resistance genes were introduced from ancestral and other wild species related to common wheat such as Triticum monococcum, close relative of the A genome progenitor Triticum uratu, the B genome progenitor Aegilops speltoides, and the D genome progenitor Ae. Tauschii (Hsam \& Zeller, 2002; Jiang et al., 1994). Chen and Chelkowski (1999) and Hsam and Zeller (2002) reported a total of 22 resistance alleles at 10 loci including Pm1, Pm2, Pm3 (3a, 3b, 3c, 3d, 3e, and 3f), Pm9, Pm18, Pm22 and Pm45 in T. aestivum indicating that Pm genes may still be found in cultivated wheat. Although Bennett (1984) reported that just a small number of $P m$ genes have been identified which originated in the cultivars T. aestivum. Mains (1933) identified that the wild wheat relatives T. monococcum (AA genomes), T. dicoccum (AABB), and T. timopheevi (AAGG) are the sources of resistance genes to powdery mildew as early as 1933. Screening of old wheat cultivars, land-races and related species for resistance to powdery mildew started in the 1930's (Hsam \& Zeller, 2002). Pm genes were identified in many different, widely distributed wheat cultivars and landraces. Pm5a and Pm5b, followed by Pm2, Pm6, and Pm8 are the most common in Europe, Asia and Mediterranean cultivars. Pm $3 a$ is commonly found in wheat cultivars grown in diverse geographical locations including the Balkans, Japan, china and the US. $P m 3 c$ was identified in Germany, while Pm3d was found in several European countries and China. Pm $4 a$ has been used in commercial wheat cultivars in Germany and China. A number of commercially grown cultivars have been found to have $P m$ gene combinations (Heun \& Fischbeck, 1987). The best known cultivars are Normandie with $P m 1, P m 2$, and $P m 9$, Maris Huntsman with $P m 2$ and $P m 6$, Kronjuvel with $P m 4 b$ and $P m 8$, and 623/65 with $P m 4 b$ and $P m 8$ (Liu et al., 1999). Gene transfer from species within the primary gene pool of Triticum that homologous chromosomes to wheat can be done directly by hybridization, recombination and backcrossing.

Diploid Aegilops tauschii Coss $(2 \mathrm{n}=2 \mathrm{x}=14, \mathrm{DD})$ has proved to be a valuable relative for wheat breeding and diversifying disease resistance (Gill et al. 1986, Cox et al. 1992). For wheat powdery mildew resistance, Gill et al. (1986) reported on the reactions of 60 accessions of A. tauschii to four Bgt isolates. Among the 60 accessions, four showed an immune reaction, seven were highly resistant, and 20 were moderately resistant. Two resistance alleles, Pm2 and pm19, were transferred into common wheat from A. tauschii (Hsam \& Zeller, 2002). Although Pm10 and Pm15 are not effective against Bgt, they can be traced from A. tauschii (McIntosh et al., 1995). Four new germplasm lines, NC96BGTD1, NC96BGTD2, were released with wheat powdery mildew resistance alleles, which were transferred from A. tauschii and two germplasm line NC96BGTD3 and NC97BGTD7 contain Pm34 and Pm35 (Murphy et al., 1998; Mirinda et al., 2006, 2007). Shi et al., (1998) identified new allele(s) for powdery mildew resistance transferred from Ae. Tauschii ssp. Tauschii in NC92-8562 and NC109-2-1-G1-1; diploid einkorn wheat (T. monococcum) $(2 \mathrm{n}=2 \mathrm{x}=14$, AA genome) derivative common wheat germplasm NC96BGTA5 contain Pm25 (Shi et al., 1998; Murphy et al., 1998).

Tetraploid wild emmer wheat (T. dicoccoides) $(2 \mathrm{n}=4 \mathrm{x}=28$, AABB), the progenitor of common tetraploid and hexaploid wheats (Liu et al., 2002); and the source of Pm16, Pm26, Pm3,Pm31,Pm36, Pm41 and pm42 (Rong et al., 2000; Liu et al., 2002; Hsam \& Zeller, 2002; Hua et al., 2009). Krivchenko et al., (1979) determined the reactions of 29 T. dicoccoides samples to wheat powdery mildew. Twenty-eight were resistant in the field, and fifteen were resistant in the seedling stage. Wang et al. (2007) reported that the temporary design powdery mildew resistance gene 
PmAS846 derived from wild emmer (T. dicoccoides) accession As846. Moseman et al. (1984) reported on the reactions to powdery mildew of 233 T. dicoccoides nti-infla. Resistance to at least one isolate was found in 149 accessions, and 137 expressed intermediate to complete resistance to four Bgt isolates; tetraploid T. dicoccum $(2 \mathrm{n}=4 \mathrm{x}=28, \mathrm{AABB})$, a source of genes for resistance to powdery mildew (Bennett, 1984; Navarro et al., 2000; Hsam and Zeller, 2002) including Pm4a and Pm5a ; tetraploid T. durum ( $2 \mathrm{n}=4 \mathrm{X}=28, \mathrm{AABB})$, a somewhat less valuable source of resistance to powdery mildew (Mains, 1934; Hsam \& Zeller, 2002), although it contributed Pm3h (Zeller and Hsam, 1998); This species is highly regarded as a source for $P m$ and other resistance genes (Mains, 1934; Grechter-Amitai and Van Silfhout, 1984; Hsam \& Zeller, 2002); tetraploid T. carthlicum $(2 \mathrm{n}=4 \mathrm{x}=28$, AABB genomes) was a donor of Pm4b and Pm33 (Hsam \& Zeller, 2002; Zhu et al., 2005).

Polyploid Triticum and Aegilops genotypes sharing at least one common genome with $T$. aestivum belong to the secondary gene pool. If genes are on the homologous chromosomes, gene transfer may be by direct hybridization, or may require special cytogenetic techniques such as embryo rescue (Jiang et al., 1994). Some diploid and tetraploid species belong to this group and some species have been used as sources of resistance genes such as; tetraploid cultivated T. timopheevii and it's wild form, T. araraticum, $(2 \mathrm{n}=4 \mathrm{x}=28$, AAGG), contributed Pm6,Pm27, Pm37 and contain at least one more Pm gene (Mains, 1934; Järve et al., 2000; Hsam \& Zeller, 2002; Murphy et al., 2002; Perugini et al., 2008); Ae. Speltoides $(2 \mathrm{n}=2 \mathrm{x}=14$, SS) was the donor of Pmld, Pm12 and Pm32 (Hsam and Zeller, 2002; Hsam et al., 2003); and Ae. Longissima (2n=2x=14, SS), was the donor of Pm13 (Cenci et al., 1999). Ae. Speltoides and Ae. Longissima are both diploid species with the $\mathrm{S}$ genome, which is closely related to the $\mathrm{B}$ genome of wheat and show co-linearity with at least five chromosomes with the wheat D genome (Zhang et al., 2001; Hsam \& Zeller, 2002). Other species such as Dasypyrum (Hylandia) $(2 \mathrm{n}=2 \mathrm{x}=14, \mathrm{VV})$, cultivated rye (Secale nti-i) $(2 \mathrm{n}=2 \mathrm{x}=14, \mathrm{RR})$, and some Aegilops species which do not share with common wheat genomes belong to the tertiary gene pool. A homologous recombination with such donor parents cannot be used for gene transfer. Genetic techniques such as induction of chromosome translocations radiated or induced mutation at Phl locus on chromosome 5BL or lack of 5B chromosomal pair can be used to facilitate gene transfer (Jiang et al., 1994). The products of these methods are wheat/alien chromosome translocation, or recombination lines. Four $\mathrm{Pm}(\mathrm{Pm} 7, \mathrm{Pm} 8$, $P m 17$, and $P m 20$ ) genes were transferred from rye (Secale $n t i-i, 2 \mathrm{n}=14, \mathrm{RR}$ ) into cultivated wheat (Hsam and Zeller, 2002). The 1 RS chromosome arm from rye is the most widely incorporated alien chromatin in present wheat genomes (Hsam et al., 2000). Wheat germplasm Transec contain $P m 7$ as a 4BS.4BL-5RL translocation (Table 1). Pm8 derived from rye cultivar Petkus (Ren et al., 1997) and Pm17 are both located on the short arm of the 1R chromosome in rye. $P m 8$ and $P m 17$ segregated independently from each other in Amigo wheat which indicated two distinct translocations. $P m 8$ is located in T1BL.1RS, and Pm17 is located in T1AL.1RS wheat-rye translocation lines (Heun et al., 1990; Friebe et al., 1994). Pm20 was transferred from the 6RL rye chromosome into common wheat. Aegilops $n t i-(2 \mathrm{n}=4 \mathrm{X}=28$, UUMM) was the donor of $P m 29$ and the wild diploid Hyanaldia vilosa $(2 \mathrm{n}=2 \mathrm{x}=14, \mathrm{VV})$ was the donor of Pm21 (Zeller et al., 2002). Other species with potentially useful powdery mildew resistance genes are Ae. nti-in, Ae. Markgrafii, Ae. Umbelluata, Ae. Variabilis, Ae. Triuncalis, and Ae. Mutica, as well as the perennial subspecies of Triticae, such as Elymus, Leymus, Elytrigia and Thinopyrum, (Jiang et al., 1994; Eser, 1998; Hsam \& Zeller, 2002; Luo et al., 2009).

\section{Molecular Markers Linked to Powdery Mildew Resistance Gene}

Molecular markers are tools that help to locate and identify parts of DNA that are located near a gene or genes of interest. DNA markers identify locations where the sequences differ among varieties. These can be located within genes or in the DNA between genes, so long as they are unique sequences and differ between the plants of interest. Differences of this type are called polymorphisms, and there are a variety of ways to detect and use these signposts within the chromosomes (Suslow et al. 2002). Different molecular techniques have been used to characterize and manipulate resistance genes and to dissect different types of resistance. Molecular markers were used for mapping monogenic resistance, characterization of quantitative resistance in germplasms and marker-aided selection (Michelmore, 1995). Molecular identification of specific DNA sequences can be used to identify the presence or absence of $P m$ genes in a cultivar, their chromosomal location, the number of genes and the way in which they are transmitted to progeny (Chen \& Chelkowski, 1999). With the help of molecular markers, more than 20 powdery mildew resistance genes, such as Pm30 (Liu et al., 2002), Pm31 (Xie et al., 2003), Pm33 (Zhu et al., 2005), Pm34 (Miranda et al., 2006), Pm35 (Miranda et al., 2007), PmY39 (Zhu et al., 2006), PmY201 and PmY212 (Sun et al., 2006), PmU (Qiu et al., 2005), MlZecl (Mohler et al., 2005), Mlm2033, Mlm80 and pm2026 (Yao et al., 2007; Xu et al., 2008), PmLK906 (Niu et al., 2008) Pm43 (He et al., 2009) and Pm45 (Ma et al., 2011), have been discovered and mapped. Molecular marker techniques commonly used for identification and confirmation of $P m$ genes to powdery mildew are: 


\subsection{Restriction Fragment Length Polymorphisms (RFLP)}

RFLPs were the first molecular markers that developed and used in genetic analysis, initially in humans (Botstein et al., 1980), and later applied to plants (Weber \& Helentjaris, 1989). Even though these markers were extensively used for mapping approaches in various plant species, they didn't fulfill the initial expectations as universal genotyping assays, since they require large amounts of DNA, are expensive and time consuming. Devos \& Gale (1993) considered the RFLP technology too slow and too expensive to use for routine screening of the mapping populations. Thus, RFLPs have limited application in wheat breeding programs that require large-scale screening of progenies from intra-specific crosses in a short time period. A large number of identified powdery mildew resistance genes have been tagged with RFLP markers in wheat, such as: Pm1, Pm2, Pm3b, Pm4a (Ma et al., 1994), Pm1, Pm2, and Pm18 (Hartl et al., 1995), Pm1c (Hartl et al., 1999), Pm2 (Mohler \& Jahoor, 1996), Pm2, Pm4a, Pm21 (Liu et al., 2000), Pm3a, Pm3b, and Pm3c (Hartl et al., 1993b), Pm3g (Sourdille et al., 1999), Pm6 (Tao et al., 2000), Pm12 (Jia et al., 1996), Pm13 (Cenci et al., 1999), Pm17 (Hsam et al., 2000), Pm21 (Liu et al., 1999), Pm26 (Rong et al., 2000), Pm27 (Järve et al., 2000) and Pm29 (Zeller et al., 2002).

\subsection{Random Amplified Polymorphisms (RAPD)}

RAPD is based on the amplification of random DNA segments using a single primer of arbitrary nucleotide sequence. Sequence information and radioactivity are not required for RAPD analysis. It is economical and easy to use. Several powdery mildew resistance genes tagged with RAPD markers, such as: Pm1 (Hu et al., 1997), Pm1, Pm2, Pm3, Pm3a, Pm3b, Pm3c, Pm4a, Pm12 (Shi, 1997), Pm13 (Cenci et al., 1999), Pm18 (Hartl et al., 1995), Pm21 (Qi et al., 1996; Liu et al., 1999), and Pm25 (Shi et al., 1998). More than forty RAPD markers and two RFLP markers have been identified to be associated with Pm1, Pm2, Pm3a, Pm3b, Pm3c, Pm4a, and Pm21 (Hartl et al., 1993b, Ma et al., 1994, Qi et al., 1996). However, most RAPD markers are dominant, and sometimes the results are difficult to reproduce. Fortunately, RAPD markers can be converted to more reliable markers, such as SCARs (sequence characterized amplified regions). For example, the RAPD marker linked to the wheat powdery mildew resistance gene Pm21 was converted to a SCAR marker (Liu et al., 1996).

\subsection{Amplified Fragment Length Polymorphisms (AFLP)}

The AFLP technique is based on selectively amplifying a subset of restriction fragments from a complex mixture of DNA fragments obtained after digestion of genomic DNA with restriction endonucleases (Vos et al., 1995). AFLP analysis is a reliable and efficient method and a powerful technique to generate large numbers of markers for the construction of high-density genetic maps (Becker et al., 1995; Keim et al., 1997), identifying specific genes (Kasuga et al., 1997; Schwarz et al., 1999) and map-based cloning of resistance genes (Buschges et al., 1997; Wei et al., 1999). Linked AFLP markers have already been found for Pmlc and Pm4a (Hartl et al., 1999), Pml7 (Hsam et al., 2000), Pm24 (Huang et al., 2000b), Pm29 (Zeller et al., 2002) and pm42 (Hua et al., 2009).

\subsection{Microsatellites (Simple Sequence Repeat, SSR)}

Microsatellites or simple sequence repeats (SSRs) are an alternative type of codominant marker more suitable for screening large populations than RFLPs. They are simple sequence repeats of only a few base pairs (1-6) that are commonly found in eukaryotic genomes (Gupta et al., 1999). Most of microsatellite markers are chromosome specific, thereby simplifying the assignment of linkage groups (Röder et al., 1998; Gupta et al., 1999). The genome specificity of microsatellite markers can also be used to recognize the arm and sub-arm localization of disease resistance genes using Chinese Spring ditelosomic and deletion stocks (Endo \& Gill 1996). Gene-flanking microsatellite markers can be assigned to chromosome arms and interval breakpoints by examining their presence or absence in ditelosomic and deletion lines (Plaschke et al., 1996; Sourdille et al., 2004). Over 1000 microsatellites from wheat are currently available (Gupta et al., 2002 ; Guyomarc'h et al., 2002 ; Huang et al., 2003b ; Röder et al., 2004 ; Song et al., 2002 ; Stephenson et al., 1998). Recently, using SSR markers, there are several powdery mildew resistance genes identified and mapped such as : Pm24 (Huang et al., 2000b), Pm27 (Järve et al., 2000), Pm30 (Liu et al., 2002), Pm33 (Zhu et al., 2005), Pm34 (Miranda et al., 2006), Pm35 (Miranda et al., 2007), Pm36 (Blanco et al., 2008) Pm40 (Luo et al., 2009), Pm41 (Li et al., 2009) pm42 (Hua et al., 2009), Pm43 (He et al., 2009) and Pm45(Ma et al., 2011).

\subsection{Sequence Tagged Site (STS)}

STS markers are single copy sequence amplified using specific primers that match the nucleotide sequences at the ends of a DNA fragment of an RFLP probe (Olson et al., 1989). This approach is extremely useful for studying the relationship between various species and linked to some specific traits (Bustos et al., 1999; Hartl et al., 1993a). RFLP probes specifically linked to a desired trait can be converted into PCR-based STS markers, based on nucleotide sequence of the probe giving polymorphic band pattern, to obtain specific amplification. Tedious hybridization 
procedures involved in RFLP analysis can be overcome using this technique. Tagged STS markers have been identified for Pml (Hu et al., 1997), Pm2 (Mohler \& Jahoor, 1996), Pm13 (Cenci et al., 1999), Pm41 (Li et al., 2009) and pm42 (Hua et al., 2009).

\section{Mapping Population}

Both $F_{2}$ and backcross populations are easy to construct and can be produced within short time. $F_{2}$ is more powerful for detecting QTLs with additive effects, and can also be used to estimate the degree of dominance for detected QTLs. When dominance is present, backcrosses give biased estimates of the effects because additive and dominant effects are completely irritating in this design (Carbonell et al., 1993). Many markers require to be analyzed for a large number of plants when $\mathrm{F}_{2}$ or backcross populations are used for gene mapping. Besides, some traits are difficult to score on an individual plant basis. So, alternative strategies have been used to improve the efficiency of genetic mapping such as NILs (near-isogenic lines), BSA (bulked segregant analysis) and RILs (recombinant inbred Lines) lines or DH (double haploid, Michelmore et al., 1991).

NILs that differ by the presence or absence of the target gene and flanking a small region of DNA, are useful to identify markers linked with the target gene (Young et al., 1988). Genetic markers are polymorphic between the NIL and its recurrent parent that are putatively linked to the target gene (Muehlbauer et al., 1988). Many disease resistance genes have been mapped using NILs, including powdery mildew resistance in wheat and barley (Hinze et al., 1991; Schuller et al., 1992). Pm2, Pm3, Pm4a and Pm6 have been mapped using NILs (Hartl et al., 1995; Tao et al., 2000).

Although NILs are helpful to construct gene map, often they are unavailable, and the development of NILs is time-consuming and laborious. To overcome the problems of NILs, Michelmore et al., (1991) successfully used bulked segregant analysis (BSA) to identify RAPD markers tightly linked to genes for resistance to lettuce downy mildew. Many powdery mildew resistance gene/allele such as Pm1, Pm4a, Pm8, Pm24, Pm25, Pm29, Pm30 and Pm31 have been identified using BSA (Shi et al., 1998). This strategy involves comparing two DNA samples pool of individuals from a segregating population. Within each pool, or bulk, the individuals are identical for the trait or gene of interest but are uninformed for all the other genes. All polymorphic markers between two DNA pools are putatively linked with the target gene.

Recombinant inbred lines or double haploid populations are permanent populations that can be used indefinitely for mapping. They can also be readily disseminated among labs and new data can be continuously added to a pre-existing map. Furthermore, RI lines or DH populations can be evaluated in many different environments. Since each genotype is represented by an inbred line, rather than by an individual plant, a more accurate assessment of the genetic component of variance can be made in studying quantitative traits (Burr et al., 1988). Therefore, RI lines or DH populations are more useful for analysis of quantitative traits or traits that are difficult to characterize on an individual plant basis. DH lines have been used to screen molecular markers associated with genes, $P m 3 a, P m 3 g$ and Pm8 for powdery mildew resistance in wheat (Hartle et al., 1993b; Sourdille et al., 1999; Wricke et al., 1996). Pm13 has been mapped using RI lines (Donini et al., 1995)

\section{Mapping of Powdery Mildew Resistance Genes}

The development of genetic maps of wheat is now adding a new dimension for identification of molecular markers associated with powdery mildew resistance genes. Screening markers can be conducted in the two parents, by selecting several markers on each chromosome of the genetic map, and then linkage between the allele for resistance and the polymorphic markers in the two parents can be estimated by use of QTL statistical analysis based on the data from a segregating population. In plants, molecular mapping and cloning of disease resistance genes will facilitate the study of molecular mechanisms underlying and evolution of resistance and will permit marker-assisted selection in breeding programs. Several powdery mildew resistance genes have been tagged with molecular markers (Table 2). Using cultivar Chancellor as the recurrent parent, Briggle (1969) developed NILs for powdery mildew resistance genes Pm1, Pm2, Pm3 and Pm4a, respectively. Hartl et al. (1995) found that RFLP marker Whs178 was $3 \mathrm{cM}$ away from gene Pm1. Hu et al. (1997) used RAPD markers to tag gene Pm1. RAPD markers UBC320420 and UBC638550 cosegregated with gene Pml among $244 \mathrm{~F}_{2}$ plants. Another RAPD marker OPF12650 was $5.4 \mathrm{cM}$ away from gene Pm1. Recently, Hartl et al. (1999) have used AFLP markers to map gene Pm1c. Among 96 primer combinations, 31 polymorphic AFLP fragments between the resistant and susceptible pools were in accordance with the patterns of the parents. The eight most reliable polymorphic markers were analyzed in a segregating population for the gene Pm1c. Two of them cosegregated with the gene Pmlc and the other six markers were tightly linked with the gene. One AFLP marker, 18M2, was found to be highly specific for the Pmlc gene in diverse genetic backgrounds. RFLP analysis of NILs possessing the gene Pm2 and the recurrent parent indicated that: 1) RFLP marker BCD1871 was $3.5 \mathrm{cM}$ away from gene Pm2 (Ma et al., 1994); 2) RFLP marker Whs295 mapped $2.7 \mathrm{cM}$ 
away from the gene Pm2 (Hartl et al., 1995); and 3) the gene Pm2 was also linked with RFLP marker Whs350 (Hartl et al., 1995). Ma et al., (2011) found that Pm45 on chromosome 5DS which was flanked by Xgwm205 and Xmag6176, with a genetic distance of $8.3 \mathrm{cM}$ and $2.8 \mathrm{cM}$, respectively. This gene was $3.3 \mathrm{cM}$ from a locus mapped by the STS marker MAG6137, converted from the RFLP marker BCD1871, which was $3.5 \mathrm{cM}$ from Pm2. Using RFLP analysis of NILs possessing the gene Pm3 and the recurrent parent, Hartl et al. (1993b) found that RFLP marker Whs179 revealed polymorphism not only between the NILs with and without gene Pm3, but also among NILs possessing different alleles of the Pm3 locus. The genetic distance between probe Whs 179 and Pm3 was $3.3 \pm 1.9 \mathrm{cM}$. Ma et al. (1994) reported that RFLP marker BCD1434 was $1.3 \mathrm{cM}$ away from Pm3a or Pm3b. Ma et al. (1994) also reported that Pm4a cosegregated with RFLP markers BCD1231-2A(2) and CDO678-2A, and was closely flanked by BCD1231-2A(1) and BCD292-2A. Xue et al. (2009) reported that SSR marker Xgwm577 was linked to powdery mildew resistance gene $m l x b d$ with a distance of 3.5cM. Blanco et al., (2008) found that Pm36 linked on chromosome 5BL with five AFLP markers XP43M32 (250), XP46M31(410), XP41M37(100), XP41M39(250) and XP39M32(120), three genomic SSR markers (Xcfd07, Xwmc75, Xgwm408) and one EST-derived SSR marker (BJ261635). Using $\mathrm{F}_{2}$ population Zhang et al. (2010) also found that the temporary design powdery mildew resistance gene Ml3D232 on chromosome 5BL which was flanked by Xgwm415 and Xwmc75. Zhang et al. (2009) also found temporary Pm design gene MIW29 on 5BL chromosome and also flanked by Xgwm415 and Xwmc75, with a genetic distance of $2.5 \mathrm{cM}$ and $17.6 \mathrm{cM}$, respectively.

\section{Conclusion}

Molecular markers tightly linked to economically important monogenic or oligogenic trait have potential for immediate utility in plant improvement. Efficient application of molecular markers in plant breeding will depend on the development cost-effective and automated diagnostic technologies. A major problem is when the linked marker used for selection is at a distance away from the gene of interest, leading to crossover between the marker and the gene. In future, the success of marker assisted selection may depend on the possibility of tagging the favorable alleles themselves.

Valuable lessons learnt from past research are likely to encourage more researchers to develop reliable markers and plant breeders to adopt MAS. PCR-based markers are more attractive for MAS, due to the small amount of template required and more efficient handling of large population sizes. PCR-based molecular markers are suitable for marker assisted selection (MAS), due to small amount of DNA require, more efficient managing of large population sizes and possible to map and tag almost any trait. DNA markers have facilitated the dissection of the genetic basis of complex traits and have helped in understanding their mode of action and how their functioning is modulated by the environment. AFLP, RAPD and STS markers can not be applied for differentiation of homozygous and heterozygous individuals in segregating population. Among the DNA marker systems of wheat, microsatellites are recently the optimal marker for MAS, because of their co-dominant inheritance, chromosome-specific and evenly distributed along chromosomes. A large numbers of microsatellite makers are available that offer identification and molecular mapping of powdery mildew resistance gene in wheat (Gupta et al., 2002; Guyomarc'h et al., 2002; Huang et al., 2001; Roder et al., 2004; Song et al., 2002; Stephenson et al., 1998). Already some Pm genes have been identified and mapped by specific nti-inflammat markers.

We believe that several other factors will greatly affect the efficiency and effectiveness of linkage mapping and MAS research in the future: new developments and improvements in marker technology, the integration of functional genomics with linkage mapping, and the availability of more high-density maps.

\section{References}

Becker, J. Vos, P. Kuiper, M. Salamini \& F. Heun, M. (1995). Combined mapping of AFLP and RFLP markers in barley. Mol. Gen. Genet, 249, 65-73. http://dx.doi.org/10.1007/BF00290237

Bennett, F. G. A. (1984). Resistance to powdery mildew in wheat: A review of its use in agriculture and breeding programmes. Plant Pathol, 33, 279-300. http://dx.doi.org/10.1111/j.1365-3059.1984.tb01324.x

Blanco, A. Gadaleta, Cenci, A. A. Carluccio, A. V. Abdelbacki \& A. M. M. Simeone. R. (2008). Molecular mapping of the novel powdery mildew resistance gene Pm36 introgressed from Triticum turgidum var. dicoccoides in durum wheat. Theor. Appl. Genet, 116, 417-425.

Bonnett, D. G. Rebetzke \& G. J. Spielmeyer, W. (2005). Strategies for efficient implantation of molecular markers in wheat breeding. Mol. Breed, 15, 75-85. http://dx.doi.org/10.1007/s11032-004-2734-5

Botsein, D. White, R. L. \& Skolnick, M. (1980). Construction of a genetic linkage map in man using restriction fragment length polymorphisms. Am. J. Hum. Genet, 32, 314-331.

Briggle L. W. (1969) Near-isogenic lines of wheat with genes for resistance to Erysiphe graminis f. sp. Tritici. 
Crop Sci, 9, 70-72. http://dx.doi.org/10.2135/cropsci1969.0011183X000900010023x

Briggle, L. W. \& Sears, E. R. (1966). Linkage of resistance to Erysiphe graminis f.sp. tritici (Pm3) and hairy glume $(\mathrm{Hg})$ on chromosome 1A of wheat. Crop Sci, 6, 559-561. http://dx.doi.org/10.2135/cropsci1966.0011183X000600060017x

Briggle, L. W. (1966). Three loci in wheat involving resistance to Erysiphe graminis f.sp. tritici. Crop Sci, 6, 461-465. http://dx.doi.org/10.2135/cropsci1966.0011183X000600050021x

Burr, B. Burr, F. A. Thompson, K. H. Albertson, M. C. \& Stuber, C. W. (1988). Gene mapping with recombinant inbreds in maize. Genetics, 118, 519-526.

Buschges, R. Hoollricher, K. Panstruga, R. et al. (1997). The barley Mlo gene: A novel control element of plant pathogen resistance. Cell, 88, 695-705. http://dx.doi.org/10.1016/S0092-8674(00)81912-1

Bustos, A. Soler \& C. Jouve, N. (1999). Analysis by PCR-based markers using designed primers to study relationships between species of Hordeum (Poaceae). Genome, 42, 129-38 (1999).

Carbonell, E. A. Asins, M. A. Baselga, M. Balansard, E. \& Gerig, T. M. (1993). Power studies in the estimation of genetic parameters of quantitative trait loci for backcross and doubled haploid populations. Theor. Appl. Genet, 86 (4), 411-416. http://dx.doi.org/10.1007/BF00838555

Cenci, A. D’Ovidio, R. Tanzarella, O. A. Ceoloni \& C. Porceddu E. (1999). Identification of molecular markers linked to Pm13, an Aegilops longissimagene conferring resistance to powdery mildew in wheat. Theor. Appl. Genet, 98, 448-454. http://dx.doi.org/10.1007/s001220051090

Ceoloni, C. DelSignore, G. Ercoli \& L. Donini, P. (1992). Locating the alien chromatin segment in common wheat-Aegilops longissima mildew resistance transfers. Hereditas, 116, 239-245.

Chantret, N. Sourdille, P. Röder, M. Tavaud, M. Bernard, M. \& Dousinault, D. (2000). Location and mapping of the powdery mildew resistance gene $M I R E$ and detection of a resistance QTL by bulked segregant analysis (BSA) with microsatellites in wheat. Theor. Appl. Genet, 100, 1217-1224. http://dx.doi.org/10.1007/s001220051427

Chen, P. D. Qi, L. L. Zhou, B. Zhang, S. Z. \& Liu, D. J. (1995). Development and molecular cytogenetic analysis of wheat-Haynaldia villosa $6 \mathrm{VS} / 6 \mathrm{AL}$ translocation lines specifying resistance to powdery mildew. Theor. Appl. Genet, 91, 1125-1129. http://dx.doi.org/10.1007/BF00223930

Chen, Y. \& Chelkowski, J. (1999). Genes for resistance to wheat powdery mildew. J. Appl. Genet, 40(4), 317-334.

Chen, Y. Zhang, Z. Y. Li, H. J. Liu, Z. Y. Veisz, O. \& Vida, G. (2011). Pm44, a new gene for powdery mildew resistance on the short arm of wheat chromosome 3A. (Draft manuscript).

Cox, T. S. Raupp, W. J. Wilson, D.L. Gill, B. S. Leath, S. Bockus, W. W. \& Browder L. E. (1992). Resistance to foliar diseases in collection of Triticum tauschii germplasm. Plant Disease, 76(10), 1061-1064. http://dx.doi.org/10.1094/PD-76-1061

DeFroidmont, D. (1998). A co-dominant marker for the 1BL/1RS wheat-rye translocation via multiplex PCR. $J$. Cereal Sci, 27, 229-232. http://dx.doi.org/10.1006/jcrs.1998.0194

Devos, K. M. \& Gale, M. D. (1993). The Genetic Maps of Wheat and their Potential in Plant Breeding. Outlook on Agriculture, 22(2), 93-99.

Donini, P. Koebner, R. M. D. \& Ceoloni, C. (1995). Cytogenetic and molecular mapping of the wheat-Aegilops longissima chromatin break points in powdery mildew resistant introgression lines. Theor. Appl. Genet, 91, 738-743. http://dx.doi.org/10.1007/BF00220952

Endo, T. R. \& Gill, B. S. (1996). The deletion stocks of common wheat. J. Hered, 87, 295-307.

Eser, V. (1998). Characterization of powdery mildew resistant lines derived from crosses between Triticum aestivum and Aegilops speltoides and Ae. Mutica. Euphytica, 100, 269-272. http://dx.doi.org/10.1023/A:1018372726968

Friebe, B. Heun, M. Tuleen, N. Zeller, F. J. \& Gill, B. S. (1994). Cytogenetically monitored transfer of powdery mildew resistance from rye into wheat. Crop Sci, 34, 621-625. http://dx.doi.org/10.2135/cropsci1994.0011183X003400030003x

Gill, B. S. Raupp, W. J. Sharma, H. C. et al. (1986). Resistance in Aegilops squarrosa to wheat leaf of rust, wheat powdery mildew, greenbug, and Hessian fly. Plant Dis, 70,553-556. http://dx.doi.org/10.1094/PD-70-553

Gill, K. S. Gill, B. S. Endo, T. R. \& Boyko, E. V. (1996a). Identification and high-density mapping of gene-rich 
regions in chromosome group 5 of wheat. Genetics, 143, 1001-1012.

Gill, K. S. Gill, B. S. Endo, T. R. \& Taylor, T. (1996b). Identification and high-density mapping of gene-rich regions in chromosome group 1 of wheat. Genetics, 144, 1883-1891.

Grechter-Amitai, Z. K. \& Van Silfhout C. H. (1984). Resistance to powdery mildew in wild emmer (Triticum dicoccoides Körn.). Euphytica, 33, 273-280.

Griffey, C. A. Das M. K. \& Stromberg E. L. (1993). Effectiveness of adult-plant resistance in reducing grain yield loss to powdery mildew in winter wheat. Plant Dis, 77, 618-622. http://dx.doi.org/10.1094/PD-77-0618

Gupta, P. K. Balyan, H. S. Edwards, K. J. et al. (2002). Genetic mapping of 66 new microsatellite (SSR) loci in bread wheat. Theor. Appl. Genet, 105, 413-422. http://dx.doi.org/10.1007/s00122-002-0865-9

Gupta, P. K. Varshney, R. K. Sharma, P. C. \& Ramesh. B. (1999). Molecular markers and their applications in wheat breeding. Plant Breeding, 118, 369-390. http://dx.doi.org/10.1046/j.1439-0523.1999.00401.x

Guyomarc'h, H., Sourdille, P. Charmet, G. Edwards K. J. \& Bernard, M. (2002). Characterisation of polymorphic microsatellite markers from Aegilops tauschii and transferability to the D-genome of bread wheat. Theor. Appl. Genet, 104, 1164-1172. http://dx.doi.org/10.1007/s00122-001-0827-7

Haley, C. S. \& Knott, S. A. (1992). A simple regression method for mapping quantitative trait loci in line crosses using flanking markers. Heredity, 69, 315-324. http://dx.doi.org/10.1038/hdy.1992.131

Hartl, L. Mohler, V. Zeller, F. J. Hsam, S. K. L. \& Schweizer, G.. (1999). Identification of AFLP markers closely linked to the powdery mildew resistance genes Pmlc and Pm4a in common wheat. Genome, 42, 322-329.

Hartl, L. Weiss, H. Stephan, U. Zeller F. J. \& Jahoor, A. (1995). Molecular identification of powdery mildew resistance genes in common wheat (Triticum aestivum L.). Theor. Appl. Genet, 90, 601-606. http://dx.doi.org/10.1007/BF00222121

Hartl, L. Weiss, H. Stephan, U. Zeller, F. J. \& Jahoor, A. (1993a). Molecular identification of powdery mildew resistance genes in common wheat (Triticum aestivum L.). Theor. Appl. Genet, 90, 01-06.

Hartl, L. Weiss, H. Zeller, F. J. \& Jahoor, A. (1993b). Use of RFLP markers for the identification of alleles of the Pm3 locus conferring powdery mildew resistance in wheat (Triticum aestivum L.). Theor. Appl. Genet, 86, 959-963. http://dx.doi.org/10.1007/BF00211048

Hautea, R. A. Coffman, W. R. Sorrells, M. E. \& Bergstrom, G. C. (1987). Inheritance of partial resistance to powdery mildew in spring wheat. Theor. Appl. Genet, 73, 609-615. http://dx.doi.org/10.1007/BF00289202

He, R. Chang, Z. Yang, Z. Yuan, Z. Zhan, H. Zhang \& X. Liu, J. (2009). Inheritance and mapping of powdery mildew resistance gene Pm43 introgressed from Thinopyrum intermedium into wheat. Theor. Appl. Genet, 118, 1173-1180. http://dx.doi.org/10.1007/s00122-009-0971-z

Heun, M. \& Fischbeck, G. (1987). Identification of wheat powdery mildew resistant genes by analyzing host-pathogen interactions. Plant Breed, 98, 124-129. http://dx.doi.org/10.1111/j.1439-0523.1987.tb01104.x

Heun, M. Friebe, B. \& Bushuk, W. (1990). Chromosomal location of the powdery mildew resistance gene of Amigo wheat. Phytopathology, 80, 1129-1133. http://dx.doi.org/10.1094/Phyto-80-1129

Hinze, K. Thompson, R. D. Ritter, E. Salamini, F. \& Schulze-Lefert, P. (1991). RFLP-mediated targeting of the ml-o resistance locus in barley (Hordeum vulgare). Proc. Natl. Acad. Sci. USA, 88, 3691-3695. http://dx.doi.org/10.1073/pnas.88.9.3691

Hsam, S. L. K. \& Zeller, F. J. (1997). Evidence of allelism between genes $P m 8$ and Pm17 and chromosomal location of powdery mildew and leaf rust resistance genes in the common wheat cultivar 'Amigo'. Plant Breed, 116, 119-122. http://dx.doi.org/10.1111/j.1439-0523.1997.tb02164.x

Hsam, S. L. K. \& Zeller, F. J. (2002). Breeding for powdery mildew resistance in common wheat (T. aestivum L. em Thell.). In: R.R.B' elanger, W.R. Bushnell, A.J. Dik \& T.L.W. Carver (Eds.), The Powdery Mildews: A Comprehensive Treatise, APS Press, St. Paul, U.S.A., pp. 219-238.

Hsam, S. L. K. Huang, X. Q. \& Zeller, F. J. (2001). Chromosomal location of genes for resistance to powdery mildew in common wheat (Triticum aestivum L.em.Thell.).6. Allelesatthe Pm5 locus. Theor. Appl. Genet, 102, 127-133. http://dx.doi.org/10.1007/s001220051627

Hsam, S. L. K. Huang, X. Q. Ernst, F. Hartl, L. \& Zeller, F. J. (1998). Chromosomal location of genes for resistance to powdery mildew in common wheat (Triticum aestivum L. em Thell). 5. Alleles at the Pm1 locus. Theor. Appl. Genet, 96, 1129-1134. http://dx.doi.org/10.1007/s001220050848 
Hsam, S. L. K. Lapochkina, I. F. \& Zeller, F. J. (2003). Chromosomal location of genes for resistance to powdery mildew in common wheat (Triticum aestivum L. em Thell.). 8. Gene Pm32 inawheat-Aegilopsspeltoides translocationline. Euphytica, 133, 367-370. http://dx.doi.org/10.1023/A:1025738513638

Hsam, S. L. K. Mohler, V. Hartl, L. Wenzel, G. \& Zeller, F. J. (2000). Mapping of powdery mildew and leaf rust resistance genes on the wheat-rye translocated chromosome T1BL.1RS using molecular and biochemical markers. Plant Breed, 119, 87-89. http://dx.doi.org/10.1046/j.1439-0523.2000.00444.x

Hu, X. Y. Ohm, H. W. \& Dweikat, I. (1997). Identification of RAPD markers linked to the gene Pml for resistance to powdery mildew in wheat. Theor. Appl. Genet, 94, 832-840. http://dx.doi.org/10.1007/s001220050484

Hua, W. Liu, Z. Zhu, J. Xie, C. Yang, T. Zhou, Y. Duan, X. Sun, Q. \& Liu, Z. (2009). Identification and genetic mapping of $P m 42$, a new recessive wheat powdery mildew resistance gene derived from wild emmer (Triticum turgidum var. dicoccoides). Theor. Appl. Genet, 119, 223-230. http://dx.doi.org/10.1007/s00122-009-1031-4

Huang, X. Q. \& Roder, M. S. (2003). High-density genetic and physical mapping of the powdery mildew resistance gene Pm24 on chromosome 1D of wheat. In: H. N. Pogna, M. Romano, E. A. Pogna and G. Galterio (Eds.), Proceedings of the $10^{\text {th }}$ International Wheat Genetics Symposium, September 1-6, 2003, Paestum, Italy, pp. 961-964.

Huang, X. Q. \& Röder, M. S. (2004). Molecular mapping of powdery mildew resistance genes in wheat: a review. Euphytica, 137, 203-223. http://dx.doi.org/10.1023/B:EUPH.0000041576.74566.d7

Huang, X. Q. Coster, H. Ganal, M. W. \& Roder, M. S. (2003a). Advanced backcross QTL analysis for the identification of quantitative trait loci alleles from wild relatives of wheat (Triticum aestivum L.). Theor. Appl. Genet, 106, 1379-1389.

Huang, X. Q. Hsam, S. L. K. Zeller, F. J. Wenzel, G. \& Mohler, V. (2000b). Molecular mapping of the wheat powdery mildew resistance gene Pm24 and marker validation for molecular breeding. Theor. Appl. Genet, 101, 407-414. http://dx.doi.org/10.1007/s001220051497

Huang, X. Q. Roder, M. S. Pestsova, Borner, E. A. \& Ganal, M. W. (2001). Development and use of wheat microsatellite markers for the characterization of germplasm of hexaploid wheat (Triticum aestivum L.). In: Proceedings of the Plant \& Animal Genome IX Conference, January 13-17, 2001, P260, San Diego, CA, USA.

Huang, X. Q. Wang, L. X. Xu, M. X. \& Roder, M. S. (2003b). Microsatellite mapping of the powdery mildew resistance gene Pm5e incommon wheat (Triticum aestivum L.). Theor. Appl. Genet, 106, 858-865.

Huang, X. Q., Hsam, S. L. K. \& Zeller, F. J. (2000a). Chromosomal location of two novel genes for resistance to powdery mildew in Chinese landraces (Triticum aestivum L.em.Thell.). J. Genet. \& Breed, 54, 311-317.

Iqbal, M. J. \& Rayburn, A. L. (1995). Identification of the 1RS rye chromosomal segment in wheat by RAPD analysis. Theor. Appl. Genet, 91, 1048-1053. http://dx.doi.org/10.1007/BF00223918

Järve, K. Peusha, H. O. Tsymbalova, J. Tamm, S. Devos, K. M. \& Eno, T. M. (2000). Chromosomal location of a Triticum timopheevii-derived powdery mildew resistance gene transferred to common wheat. Genome, 43, 377-381.

Jia, J. Devos, K. M. Chao, S. Miller, T. E. Reader, S. M. \& Gale, M. D. (1996). RFLP-based maps of the homoeologous group- 6 chromosomes of wheat and their application in the tagging of $P m 12$, a powdery mildew resistance gene transferred from Aegilops speltoides to wheat. Theor. Appl. Genet, 92, 559-565. http://dx.doi.org/10.1007/BF00224558

Jiang, J. Friebe, B. \& Gill, B. (1994). Recent advances in alien gene transfer in wheat. Euphytica, 73, 199-212. http://dx.doi.org/10.1007/BF00036700

Jones, N. Ougham, H. \& Thomas, H. (1997). A Markers and mapping: we are all geneticists now. New Phytologist, 137,165-177. http://dx.doi.org/10.1046/j.1469-8137.1997.00826.x

Jørgensen, J.H. (1973). Gene Pm6 for resistance to powdery mildew in wheat. Euphytica, 22, 43.

Kasuga, T. Salimath, S. S. Shi, J. Gijzen, M. Buzzell, R. I. \& Bhattacharyya, M. K. (1997). High resolution genetic and physical mapping of molecular markers linked to the Phytophthora resistance gene Rps1-k in soybean. Mol. Plant-Microbe Interact, 10, 1035-1044. http://dx.doi.org/10.1094/MPMI.1997.10.9.1035

Keim, P. Schupp, J. M. Travis, S. E. Clayton, K. Zhu, T. Shi, L. Ferreira, A. \& Webb, D. M. (1997). A high-density soybean genetic map based on AFLP markers. Crop Sci, 37, 537-543. 
http://dx.doi.org/10.2135/cropsci1997.0011183X003700020038x

Krivchenko, V. I., Migushova, E. F. \& Pavlov, P. A. (1979). Role of genomes in powdery mildew resistance in wheat. Genetika, 15, 193-198.

Law, C. N. \& Wolfe, M. S. (1966). Location for genetic factors for mildew resistance and ear emergence time on chromosome 7B of wheat. Can. J. Genet. Cytol, 8, 462-470.

Leath, S. \& Bowen, K. L. (1989). Effects of powdery mildew, triadimenol seed treatment, and triadimefon foliar sprays on yield of winter wheat in North Carolina. Phytopathol, 79(2), 152-155. http://dx.doi.org/10.1094/Phyto-79-152

Leath, S. \& Heun, M. (1990). Identification of powdery mildew resistance genes in cultivars of soft red winter wheat. Plant Dis, 74, 747-752. http://dx.doi.org/10.1094/PD-74-0747

Leath, S. \& Murphy, J. P. (1985). Virulence genes of the wheat powdery mildew fungus, Erysiphe graminis f. sp. Tritici in North Carolina. Plant Dis, 69, 905. http://dx.doi.org/10.1094/PD-69-905e

Li, G. Fang, T. Zhang, H. et al. (2009). Molecular identification of a new powdery mildew resistance gene Pm41 on chromosome 3BL derived from wild emmer (Triticum turgidum var. dicoccoides). Theor. Appl. Genet, 119, 531-539. http://dx.doi.org/10.1007/s00122-009-1061-y

Lillemo, M. Asalf, B. Singh, R. Huerta-Espino, P. J. Chen, X. M. He, Z. H. Bjornstad, A. (2008). The adult plant rust resistance loci $\operatorname{Lr} 34 / \mathrm{Yr} 18$ and $\operatorname{Lr} 46 / \mathrm{Yr} 29$ are important determinants of partial resistance to powdery mildew in bread wheat line Saar. Theor. Appl. Genet, 116, 1155-66. http://dx.doi.org/10.1007/s00122-008-0743-1

Limpert, E. Felsenstein, F. G. \& Andrivon, D. (1987). Analysis of virulence in populations of wheat powdery mildew in Europe. J. Phytopathol, 120, 1-8. http://dx.doi.org/10.1111/j.1439-0434.1987.tb04408.x

Liu Z. Sun, Q. \& Yang, T. (1999). Development of SCAR markers linked to the Pm21 gene conferring resistance to powdery mildew in common wheat. Plant Breed, 118, 215-219. http://dx.doi.org/10.1046/j.1439-0523.1999.118003215.x

Liu, D. J., Liu, J. Y. Tao, W. J. \& Chen, P. D. (1998). Molecular markers and breeding wheat for powdery mildew resistance. In: A. E. Slinkard (Ed.), Proceedings of the $9^{\text {th }}$ International Wheat Genet Symposium, University Extension Press, Saskatoon, Canada, Vol.3, pp. 128-131.

Liu, J. Liu, D. Tao, W. Li, W. Wang, S. Chen, P. Cheng, S. \& Gao, D. (2000). Molecular marker-facilitated pyramiding of different genes for powdery mildew resistance in wheat. Plant Breed, 119, 21-24. http://dx.doi.org/10.1046/j.1439-0523.2000.00431.x

Liu, L. N. Song, R. J. \& Zhang, Q. Q. (1989). Monosomic analysis of resistance to powdery mildew in wheat variety Kenguia 1. Hereditas-Beijing, 11, 1-3.

Liu, Z. Sun, Q. Ni, Z. Nevo, E. \& Yang, T. (2002). Molecular characterization of a novel powdery mildew resistance gene Pm30 in wheat originating from wild emmer. Euphytica, 123, 21-29. http://dx.doi.org/10.1023/A:1014471113511

Luo, P. G., Luo, H. Y. Chang, Z. J. Zhang, H. Y. Zhang, M. \& Ren, Z. L. (2009). Characterization and chromosomal location of $P m 40$ in common wheat: a new gene for resistance to powdery mildew derived from Elytrigia intermedium. Theor Appl. Genet, 18, 1059-1064. http://dx.doi.org/10.1007/s00122-009-0962-0

Lutz, J. Hsam, S. L. K. Limpert, E. \& Zeller, F. J. (1995). Chromosomal location of powdery mildew resistance genes in Triticum aestivum L. (common wheat ). 2. Genes Pm2 and Pm19 from Aegilops squarrosa L. Heredity, 74, 152-156. http://dx.doi.org/10.1038/hdy.1995.22

Ma, H. Kong, Z. Fu, B. Li, N. Zhang, L. Jia, H. \& Ma, Z. (2011). Identification and mapping of a new powdery mildew resistance gene on chromosome $6 \mathrm{D}$ of common wheat. Theor. Appl. Genet. http://dx.doi.org/10.1007/s00122-011-1651-3

Ma, Z. Q. Sorrells, M. E. \& Tanksley, S. D. (1994). RELP markers linked to powdery mildew resistance genes Pm1, Pm2, Pm3, and Pm4 in wheat. Genome, 37, 871-875. http://dx.doi.org/10.1139/g94-123

Mains, E. B. (1933). Host specialization of Erysiphe graminis tritici, Proc. Natl. Acad. Sci. USA, 19, 49-53. http://dx.doi.org/10.1073/pnas.19.1.49

Mains, E. B. (1934). Inheritance of resistance to powdery mildew, Erysiphe graminis tritici, in wheat. Phytopathology, 24, 1257-1261.

McIntosh, R. A. \& Baker, E. P. (1970). Cytogenetical studies in wheat. IV. Chromosome location and linkage 
studies involving the Pm2 locus for powdery mildew resistance. Euphytica, 19, 71-77. http://dx.doi.org/10.1007/BF01904668

McIntosh, R. A. Hart, G.. E. \& Gale, M. D. (1995). Catalogue of gene symbols for wheat. Page 1333-1500 In:Z. S. Li and Z. Y. Xin eds. Proceedings $8^{\text {th }}$ International Wheat genetics symposium, Beijing, China, 1993.

McIntosh, R. A., Hart, G.E. Gale, M. D. \& Rogers, W. J. (1998). Catalogue of gene symbols for wheat. In: A. E. Slinkard (Ed.), Proceedings of the $9^{\text {th }}$ International Wheat Genet Symposium, University Extension Press, University of Saskatchewan, Saskatoon, Canada, Vol. 5, pp.1-235.

McIntosh, R. A., Yamazaki, Y. Dubcovsky, J., et al. (2008). Catalogue of Gene Symbols for Wheat. http://wheat.pw.usda.gov/GG2/Tr it icum/wgc/2008/. Verified 17 March 2010.

Menzies, J. G. \& MacNeil, B. H. (1986). Virulence of Erysiphe graminis f. sp. Tritici in southern Ontario in 1983, 1984, and 1985. Can. J. Plant Pathol, 8, 338-341. http://dx.doi.org/10.1080/07060668609501810

Michelmore, R. W. Paran, I. \& Kesseli, R. V. (1991). Identification of markers linked to disease-resistance genes by bulked segregant analysis: A rapid method to detect markers in specific genomic regions by using segregating populations. Proc. Natl. Acad Sci, 88, 9828-9832. http://dx.doi.org/10.1073/pnas.88.21.9828

Mingeot, D. Chantret, N. Baret, P., et al. (2002). Mapping QTL involved in adult plant resistance to powdery mildew in the winter wheat line RE714 in two susceptible backgrounds. Plant Breed, 121, 133-140. http://dx.doi.org/10.1046/j.1439-0523.2002.00679.x

Miranda, L. M. Murphy, J. Marshall, P. D. \& Leath, S. (2006). Pm34: A new powdery mildew resistance gene transferred from Aegilops tauschii Coss. To common wheat (Triticum aestivum L.). Theor. Appl. Genet, 113, 1497-1504. http://dx.doi.org/10.1007/s00122-006-0397-9

Miranda, L. M. Murphy, J. Marshall, P. D. Cowger, C. \& Leath, S. (2007). Chromosomal location of Pm35, a novel Aegilops tauschii derived powdery mildew resistance gene introgressed into common wheat (Triticum aestivum L.). Theor. Appl. Genet, 114, 1451-1456. http://dx.doi.org/10.1007/s00122-007-0530-4

Mohler, V Hsam, S. L. K. Zeller, F. J. \& Wenzel, G.. (2001). An STS marker distinguishing the rye-derived powdery mildew resistance alleles at the Pm8/Pm17 locus of common wheat. Plant Breed, 120, 448-450. http://dx.doi.org/10.1046/j.1439-0523.2001.00622.x

Mohler, V. \& Jahoor, A. (1996). Allele specific amplification of polymorphic sites for the detection of powdery mildew resistance loci in cereals. Theor. Appl. Genet, 93, 1078-1082. http://dx.doi.org/10.1007/BF00230128

Moseman, J. G.. Nevo, E. El Morshidy, M. A. \& Zohary, D. (1984). Resistance of Triticum dicoccoides to infection with Erysiphe graminis f. sp. Tritici. Euphytica, 33, 41-47. http://dx.doi.org/10.1007/BF00022748

Muehlbauer, G. J. Specht, J. E. Thomas-Compton, M. A. Staswick, P. E. \& Bernard, R. L. (1988). Near-isogenic lines - a potential resource in the integration of conventional and molecular marker linkage maps. Crop Sci, 28, 279-735. http://dx.doi.org/10.2135/cropsci1988.0011183X002800050002x

Murphy, J. P. Leath, S. Huynh, D. Navarro, R. A. \& Shi, A. (1998). Registration of NC96BGTD1, NC96BGTD2, and NC96BGTD3 wheat germplasm resistant to powdery mildew. Crop Sci, 38, 570. http://dx.doi.org/10.2135/cropsci1998.0011183X003800020097x

Murphy, J. P. Navarro, R. A. \& Leath, S. (2002). Registration of NC99BGTAG11 Wheat germplasm resistant to powdery mildew. Crop Sci, 42, 1382. http://dx.doi.org/10.2135/cropsci2002.1382

Namuco, L. O. Coffman, W. R., Bergstrom, G. C. \& Sorrells, M. E. (1987). Virulence spectrum of the Erysiphe graminis f. sp. Tritici population in New York. Plant Dis, 71, 539-541. http://dx.doi.org/10.1094/PD-71-0539

Navarro, R. A. Murphy, J. P. \& Leath, S. (2000). Registration of NC97BGTAB9, and NC97BGTAB10 wheat germplasm lines resistant to powdery mildew. Crop Sci, 40, 1508-1509.

Neu, C. Stein, N. \& Keller, B. (2002). Genetic mapping of the Lr20- Pm1 resistance locus reveals suppressed recombination on chromosome arm 7AL in hexaploid wheat. Genome, 45, 737-744. http://dx.doi.org/10.1139/g02-040

Niu, J. S. Wang, B. Q. Wang, Y. H. Cao, A. Z. Qi, Z. J. \& Shen, T. M. (2008).Chromosome location and microsatellite markers linked to a powdery mildew resistance gene in wheat line "Lankao 90(6)". Plant Breed, 127, 346-349. http://dx.doi.org/10.1111/j.1439-0523.2007.01480.x

Olson, M. Hood, L. Cantor, C. \& Doststein, D. (1989). A common language for physical mapping of the human genome. Science, 254, 1434-1435. http://dx.doi.org/10.1126/science.2781285 
Paillard, S. Goldringer, I. Enjalbert, J. Doussinault, G. de Vallavielle-Pope, C. \& Brabant, P. (2000). Evolution of resistance against powdery mildew in winter wheat populations conducted under dynamic management. I- Is specific seedling resistance selected?. Theor. Appl. Genet, 101, 449-456. http://dx.doi.org/10.1007/s001220051502

Pedersen, W. L. \& Leath, S. (1988). Pyramiding major genes for resistance to maintain residual effects. Annu. Rev. Phytopathol, 26, 369-378. http://dx.doi.org/10.1146/annurev.py.26.090188.002101

Perugini, L. D. Murphy, J. P. Marshall, D. \& Brown-Guedira, G.. (2008). Pm37, a new broadly eVective powdery mildew resistance gene from Triticum timopheevii. Theor. Appl. Genet, 116, 417-425. http://dx.doi.org/10.1007/s00122-007-0679-x

Peusha, H. Enno, T. \& Priilinn, O. (2000). Chromosome location of powdery mildew resistance genes and cytogenetic analysis of meiosis in common wheat cultivar Meri. Hereditas, 132, 29-34. http://dx.doi.org/10.1111/j.1601-5223.2000.00029.x

Peusha, H. Hsam, S. L. K. \& Zeller, F. J. (1996). Chromosomal location of powdery mildew resistance genes in common wheat (Triticum aestivum L. em. Thell. ). 3. Gene Pm22 in cultivar Virest. Euphytica, 91, 149-152.

Plaschke, J. B. Börner, A. Wendehake, K. Ganal, M.W. \& Röder, M. S. (1996). The use of aneuploids for the chromosomal assignment of microsatellite loci. Euphytica, 89, 33-40. http://dx.doi.org/10.1007/BF00015716

Qi, L. L. Cao, M. S. Chen, P. D. Li, W. L. \& Liu, D. J. (1996). Identification, mapping, and application of polymorphic DNA associated with resistance gene Pm21 of wheat. Genome, 39, 191-197. http://dx.doi.org/10.1139/g96-025

Qi, L. L. Chen, P. D. \& Liu, D. J. (1995). The gene Pm21- a new source for resistance to resistance to wheat powdery mildew. Acta Agronomica Sinica, 21, 257-262.

Qiu, Y. C. Zhou, R. H. Kong, X, Y, Zhang, S. S. \& Jia, J. Z. (2005). Microsatellite mapping of a Triticum urartu Tum. Derived powdery mildew resistance gene transferred to common wheat (Triticum aestivum L.). Theor. Appl. Genet, 111, 1524-1531. http://dx.doi.org/10.1007/s00122-005-0081-5

Reader, S. M. \& Miller, T. E. (1991). The introduction into breed wheat of a major gene for resistance to powdery mildew from wild emmer wheat. Euphytica, 53(1), 57-60. http://dx.doi.org/10.1007/BF00032033

Ren, S. X. McIntosh, R. A. \& Lu, Z. J. (1997). Genetic suppression of the cereal rye-derived gene Pm8 in wheat. Euphytica, 93, 353-360. http://dx.doi.org/10.1023/A:1002923030266

Robe, P. \& Doussinault, G. (1995). Genetic analysis of powdery mildew resistance of a winter wheat line, RE714, and identification of a new specific-resistance gene. Plant Breed, 114, 387-391. http://dx.doi.org/10.1111/j.1439-0523.1995.tb00817.x

Roder, M. S. Huang, X. Q. \& Ganal, M. W. (2004). Wheat microsatellites in plant breeding - Potential and implications. In: H. Lorz \& G.Wenzel (Eds.), Molecular Markers in Plant Breeding and Crop Improvement. Springer-Verlag, Heidelberg.

Roder, M. S. Korzun, V. Wendehake, K. Plaschke, J. Tixier, M. Leroy, P. \& Ganal, M. W. (1998). A microsatellite map of wheat. Genetics, 149, 2007-2023.

Rong, J. K. Millet, E. Manisterski, J. \& Feldman, M. (2000). A new powdery mildew resistance gene: Introgression from wild emmer into common wheat and RFLP-based mapping. Euphytica, 115, 121-126. http://dx.doi.org/10.1023/A:1003950431049

Royer, M. H. Nelson, R. R. Mac Kenzie, D. R. \& Diehle, D. A. (1984). Partial resistance of near-isogenic lines compatible with Erysiphe graminis f. sp. Tritici. Phytopathology, 74, 1001-1006. http://dx.doi.org/10.1094/Phyto-74-1001

Schmolke, M. Mohler, V. Hartl, L. Zeller, F. J. \& Hsam, S. L. K. (2011). A novel powdery mildew resistance allele at the Pm4 locus from einkorn wheat (Triticum monococcum). Mol. Breeding (Online).

Schuller, C. Backes, G. Fischbeck, G. \& Jahoor, A. (1992). RFLP markers to identify the alleles on the Mla locus conferring powdery mildew resistance in barley. Thoer. Appl. Genet, 84, 330-338. http://dx.doi.org/10.1007/BF00229491

Schwarz, G., Michalek, W., Mohler, V. Wenzel, G. \& Jahoor, A. (1999). Chromosome landing at the Mla locus in barley (Hordeum vulgare L.) by means of high-resolution mapping with AFLP markers. Theor. Appl. Genet, 98, 521-530. http://dx.doi.org/10.1007/s001220051100 
Shaner, G. (1973). Evaluation of slow-mildewing resistance of Knox wheat in the field. Phytopathology, 63, 867-872. http://dx.doi.org/10.1094/Phyto-63-867

Shi, A. N. (1997). Genetic analysis of wheat powdery mildew resistance. Ph.D. Thesis North Carolina State University.

Shi, A. N. Leath, S. \& Murphy, J. P. (1998). A major gene for powdery mildew resistance transferred to common $\begin{array}{lllll}\text { wheat from wild eikorn wheat. Phytopathology, } & \text { 88(2), } & \text { 144-147. }\end{array}$ http://dx.doi.org/10.1094/PHYTO.1998.88.2.144

Singrun, C. H. Hsam, S. L. K. Hartl, L. Zeller, F. J. \& Mohler, V. (2003). Powdery mildew resistance gene Pm22 incultivar Virest is a member of the complex Pml locus in common wheat (Triticum aestivum L. em Thell.). Theor. Appl. Genet, 106, 1420-1424.

Song, Q. J. Fickus, E. W. \& Cregan, P. B. (2002). Characterization of trinucleotide SSR motifs in wheat. Theor. Appl. Genet, 104, 286-293. http://dx.doi.org/10.1007/s001220100698

Sourdille, P. Robe, P. Tixier, M.-H. et al. (1999). Location of Pm3g, a powdery mildew resistance allele in wheat, by using a monosomic analysis and by identifying associated molecular markers. Euphytica, 110, 193-198. http://dx.doi.org/10.1023/A:1003713219799

Sourdille, P. Singh, S. Cadalen, T. et al. (2004). Microsatellite-based deletion bin system for the establishment of genetic-hysical map relationships in wheat (Triticum aestivum L.). Funct Integr Genomics, 4, 12-25. http://dx.doi.org/10.1007/s10142-004-0106-1

Spielmeyer, W. McIntosh, R. A. Kolmer, J. \& Lagudahe, S. (2005). Powdery mildew resistance and Lr34/Yr18 genes for durable resistance to leaf and stripe rust cosegregate at a locus on the short arm of chromosome 7D of wheat. Theor. Appl. Genet, 111, 731-735. http://dx.doi.org/10.1007/s00122-005-2058-9

Starling, T. M. Roane, C. W. \& Camper, H. M. (1984). Registration of Massey wheat. Crop Sci, 24, 1000. http://dx.doi.org/10.2135/cropsci1984.0011183X002400050051x

Stephenson, P. Bryan, G. Kirby, J. Collins, A. Devos, K. Busso, C. \& Gale, M. (1998). Fifty new microsatellite loci for the wheat genetic map. Theor. Appl. Genet, 97, 946-949. http://dx.doi.org/10.1007/s001220050975

Sun, X. Liu, D. Zhang, H. Huo, N. Zhou, R. \& Jia, J. (2006). Identification and mapping of two new genes conferring resistance to powdery mildew from Aegilops tauschii (Coss.) Schmal. J. Integr. Plant Biol, 48, 1204-1209. http://dx.doi.org/10.1111/j.1744-7909.2006.00328.x

Suslow, T. Thomas, B. \& Bradford, K. (2002). Biotechnology provides new tools for plant breeding .Agricultural Biotechnology (http://www.plantsciences.ucdavis.edu/bradford/8043).

Tao, W. Liu, D. Liu, J. Feng, Y. \& Chen, P. (2000). Genetic mapping of the powdery mildew resistance gene Pm6 in wheat by RFLP analysis. Theor. Appl. Genet, 100, 564-568. http://dx.doi.org/10.1007/s001220050074

The, T. T. McIntosh, R. A. \& Bennett, F. G. A. (1979). Cytogenetical studies in wheat. IX. Monosomic analysis, telocentric mapping and linkage relationship of gene Sr21, Pm4 and Mle. Aust. J. Biol. Sci, 32, 115-125.

Tosa, Y. Sakai, K. (1990). The genetics of resistance of hexaploid wheat to the wheat grass powdery mildew fungus. Genome, 33, 225-230. http://dx.doi.org/10.1139/g87-145

Tosa, Y. Tokunaga, H. \& Ogura, H. (1988). Identification of a gene for resistance to wheat grass powdery mildew fungus in the common wheat cultivar ChineseSpring. Genome, 30, 612-614.

Tosa, Y. Tsujimoto, H. \& Ogura, H. (1987). A gene involved in the resistance of wheat to wheat grass powdery mildew fungus. Genome, 29, 850-852.

Vos, P. Hogers, R. Bleeker, M. et al. (1995). AFLP: a new technique for DNA fingerprinting. Nucleic Acids Res, 23, 4407-4414. http://dx.doi.org/10.1093/nar/23.21.4407

Wang, C. Y. Ji, W. Q. Zhang G. S. Wang, Q. Y. Cai, D. M. \& Xue, X. Z. (2007). SSR markers and preliminary chromosomal location of a powdery mildew resistance gene in common wheat germplasm N9134. Acta Agronomica Sinica, 33(1), 163-166.

Weber, D. \& Helentjaris, T. (1989). Mapping RFLP loci in maize using B-A translocations. Genetics 121: 583-590.

Wei, F. Gobelman-Werner, K. Morroll, S. M. et al. (1999). The Mla (powdery mildew) resistance cluster is associated with three NBS-LRR gene families and suppressed recombination within a 240-kb DNA interval on chromosome 5S (1HS) of barley. Genetics, 153, 1929-1948. 
Wolf, M. S. (1984). Trying to understand and control powdery mildew. Plant Pathol, 33, 451-466. http://dx.doi.org/10.1111/j.1365-3059.1984.tb02868.x

Wricke, G. Dill, P. \& Senft, P. (1996). Linkage between a major gene for powdery mildew resistance and an RFLP marker on chromosome $1 \mathrm{R}$ of rye. Plant Breed, 115, 71-73. http://dx.doi.org/10.1111/j.1439-0523.1996.tb00874.x

Xie, C. Sun, Q. Ni, Z. Yang, T. Nevo, E. \& Fahima, T. (2003). Chromosomal location of a Triticum dicoccoides-derived powdery mildew resistance gene in common wheat by using microsatellite markers. Theor. Appl. Genet, 106, 341-345.

$\mathrm{Xu}, \mathrm{H}$. Yao, G. Xiong, L. et al. (2008). Identification and mapping of pm2026: a recessive powdery mildew resistance gene in an einkorn (Triticum monococcum L.) accession. Theor. Appl. Genet, 117, 471-477. http://dx.doi.org/10.1007/s00122-008-0791-6

Xue, F. Zhai, W. W. Duan, X. Y. Zhou, Y. L. \& Ji W. Q. (2009). Microsatellite mapping of a Powdery mildew resistance gene in wheat landrace Xiaobaidong. Acta Agronomica Sinica, 35(10), 1806-1811. http://dx.doi.org/10.1016/S1875-2780(08)60109-1

Yao, G. Zhang, J. Yang, L. et al. (2007). Genetic mapping of two powdery mildew resistance genes in einkorn (Triticum monococcum L.) accessions. Theor. Appl. Genet, 114, 351-358. http://dx.doi.org/10.1007/s00122-006-0438-4

Young, N. D. Zamir, D. Ganal, M. W. \& Tanksley, S. D. (1988). Use of isogenic lines and simultaneous probing to identify DNA markers tightly linked to the Tm-2a gene in tomato. Genetics, 120, 579-585.

Zeller, F. J. \& Hsam, S. L. K.. (1998). Progress in breeding for resistance to powdery mildew in common wheat (Triticum aestivum L.). p. 178-180.In Slinkard, A. E. (ed). Proceedings of the $9^{\text {th }}$ International Wheat Genetics Symposium. Vol.1. University of Saskatchewan, Saskatoon, Canada

Zeller, F. J. Kong, L. Hartl, L. Mohler, V. \& Hsam, S. L. K. (2002). Chromosomal location of genes for resistance to powdery mildew in common wheat (Triticum aestivum L. em Thell.) 7. Gene Pm29 in line Pova. Euphytica, 123, 187-194. http://dx.doi.org/10.1023/A:1014944619304

Zeller, F. J. Lutz, J. \& Stephan, U. (1993a). Chromosome location of genes for resistance to powdery mildew in common wheat (Triticum aestivum L.).1. Mlk and other alleles at the Pm3 locus. Euphytica, 68, 223-229. http://dx.doi.org/10.1007/BF00029876

Zeller, F. J. Lutz, J. Reimlein, E. I. Limpert, E. \& Koening, J. (1993b). Identification of powdery mildew resistance genes in common wheat (Triticum aestivum L). II. French cultivas. Agronomie, 13, 201-207. http://dx.doi.org/10.1051/agro:19930304

Zhang, H. Reader, S. M. Liu, X. Jia, J. Z. Gale, M. D. \& Devos, K. M. (2001). Comparative genetic analysis of the Aegilops longissima and Ae. Sharonensis genomes with common wheat. Theor. Appl. Genet, 103, 518-525. http://dx.doi.org/10.1007/s001220100656

Zhou, R. Zhu, Z. Kong, X. Huo, N. Tian, Q. Li, P. Jin, C. Dong, Y. \& Jia, J. (2005). Development of wheat near-isogenic lines for powdery mildew resistance. Theor. Appl. Genet, 110, 640-648. http://dx.doi.org/10.1007/s00122-004-1889-0

Zhu Z, Zhou R, Kong X, Dong Y \& Jia J (2005). Microsatellite markers linked to 2 powdery mildew resistance genes introgressed from Triticum carthlicum accession PS5 into common wheat. Genome, 48, 585-590. http://dx.doi.org/10.1139/g05-016

Zhu, Z. Zhou, R. Kong, X. Dong, Y. \& Jia, J. (2006). Microsatellite marker identification of a Triticum aestivum-Aegilops umbellulata substitution line with powdery mildew resistance. Euphytica, 150, 149-153. http://dx.doi.org/10.1007/s10681-006-9103-x 
Table 1. Chromosomal location, cultivar/line, source and Reference of identified powdery mildew resistance genes

\begin{tabular}{|c|c|c|c|c|}
\hline Gene & Location & Cultivar/line & Source & Reference \\
\hline Pmla & $7 \mathrm{AL}$ & Axminister & T. aestivum & Hsam et al., 1998 \\
\hline$P m 1 b$ & $7 \mathrm{AL}$ & MocZlatka & T. monocoсcum & Hsam et al., 1998 \\
\hline $\operatorname{Pm} 1 c(P m 18)$ & $7 \mathrm{AL}$ & Weihestephan M1N & T. aestivum & Hsam et al., 1998 \\
\hline Pmld & $7 \mathrm{AL}$ & $\begin{array}{l}\text { T. spelta var. } \\
\text { duhamelianum }\end{array}$ & T. spelta & Hsam et al., 1998 \\
\hline $\begin{array}{l}\text { Pmle } \\
\text { (Pm22) }\end{array}$ & $7 \mathrm{AL}$ & Virest & T. aestivum & Singrun et al., 2003 \\
\hline Pm2 & $5 \mathrm{DS}$ & Ulka/XX 194 & T. aestivum/Ae. Tauschii & $\begin{array}{c}\text { McIntosh \& Baker, } \\
1970 \text { and Lutz et } \\
\text { al.,1995 }\end{array}$ \\
\hline$P m 3 a$ & $1 \mathrm{AS}$ & Asosan & & Briggle \& Sears, 1966 \\
\hline$P m 3 b$ & $1 \mathrm{AS}$ & Chul & T. aestivum & Briggle,1966 \\
\hline$P m 3 c$ & $1 \mathrm{AS}$ & Sonora & T. aestivum & Briggle, 1966 \\
\hline$P m 3 d$ & $1 \mathrm{AS}$ & Kolibri & T. aestivum & Zeller et al.,1993a \\
\hline$P m 3 e$ & $1 \mathrm{AS}$ & $\mathrm{W} 150$ & T. aestivum & Zeller et al.,1993a \\
\hline$P m 3 f$ & $1 \mathrm{AS}$ & Michigan Amber & T. aestivum & Zeller et al.,1993a \\
\hline$P m 3 g$ & $1 \mathrm{AS}$ & Aristide & T. aestivum & Zeller \& Hsam, 1998 \\
\hline$P m 3 h$ & $1 \mathrm{AS}$ & Abessi & T. durum & Zeller \& Hsam,1998 \\
\hline$P m 3 i$ & $1 \mathrm{AS}$ & N324 & T. aestivum & Zeller \& Hsam, 1998 \\
\hline$P m 3 j$ & $1 \mathrm{AS}$ & GUS 122 & T. aestivum & Zeller \& Hsam, 1998 \\
\hline$P m 4 a$ & $2 \mathrm{AL}$ & Khapli & T. dicoccum & The et al., 1979 \\
\hline$P m 4 b$ & $2 \mathrm{AL}$ & Armada & T. carthlicum & The et al., 1979 \\
\hline$P m 4 d$ & $2 \mathrm{AL}$ & $\operatorname{Tm} 27 \mathrm{~d} 2$ & T. monococcum & Schmolke et al., 2011 \\
\hline$P m 5 a$ & $7 \mathrm{BL}$ & Hope & T. dicoccum & Law \& Wolfe, 1966 \\
\hline$P m 5 b$ & $7 \mathrm{BL}$ & Ibis & T. aestivum & Hsam et al., 2001 \\
\hline $\operatorname{Pm} 5 \mathrm{c}$ & $7 \mathrm{BL}$ & Kolandi & $\begin{array}{l}\text { T. aestivum ssp. } \\
\text { Sphaerococcum }\end{array}$ & Hsam et al., 2001 \\
\hline$P m 5 d$ & $7 \mathrm{BL}$ & IGV 1-455 & T. aestivum & Hsam et al., 2001 \\
\hline$P m 5 e$ & $7 \mathrm{BL}$ & Fuzhuang 30 & T. aestivum & Huang et al. 2003a \\
\hline$m l x b d(P m 5)$ & $7 \mathrm{BL}$ & Xiaobaidong & T. aestivum & Huang et al., 2000a \\
\hline Pm6 & $2 \mathrm{BL}$ & TP 114 & T. timopheevii & Jørgensen,1973 \\
\hline$P m 7$ & 4BS.4BL-2RL & Transec & S.cereale & Friebe et al., 1994 \\
\hline$P m 8$ & 1RS.1BL & Disponent & S.cereale & Hsam \& Zeller, 1997 \\
\hline$P m 9$ & $7 \mathrm{AL}$ & N14 & T. aestivum & Hsam et al., 1998 \\
\hline Pm10 & 1D & Norin 26 & T. aestivum & Tosa et al., 1987 \\
\hline Pm11 & $6 \mathrm{BS}$ & Chinese Spring & T. aestivum & Tosa et al., 1988 \\
\hline Pm12 & 6BS-6SS.6SL & Trans.line 31 & Ae.speltoides & Jia et al., 1996 \\
\hline Pm13 & $\begin{array}{l}\text { 3BL.3SS-3S } \\
\text { 3DL.3SS-3S }\end{array}$ & Cstrans.line & Ae.longissima & Ceoloni et al., 1992 \\
\hline
\end{tabular}




\begin{tabular}{|c|c|c|c|c|}
\hline Gene & Location & Cultivar/line & Source & Reference \\
\hline$P m 14$ & $6 \mathrm{BS}$ & Norin 10 & T. aestivum & Tosa \& Sakai, 1990 \\
\hline$P m 15$ & 7DS & Norin 26 & T. aestivum & Tosa \& Sakai, 1990 \\
\hline Pm16 & $4 \mathrm{~A}$ & Norman rec. line & T. dicoccoides & Reader \& Miller, 1991 \\
\hline$P m 17$ & 1RS.1AL & Amigo & S.cereale & Heun et al., 1990 \\
\hline Pm19 & $7 \mathrm{D}$ & XX 186 & Ae.tauschii & Lutz et al., 1995 \\
\hline $\operatorname{Pm} 20$ & 6BS.6RL & KS93WGRC28 & S.cereale & Friebe et al., 1994 \\
\hline$P m 21$ & 6VS.6AL & Yangmai 5 line & Haynaldia villosa & Chen et al., 1995 \\
\hline$P m 23(P m 4 c)$ & $2 \mathrm{AL}$ & $82-7241$ & T. aestivum & McIntosh et al., 1998 \\
\hline$P m 24$ & $1 \mathrm{DS}$ & Chiyacao & T. aestivum & Huang et al., 2000b \\
\hline$P m 25$ & $1 \mathrm{~A}$ & NC96BGTA5 & T. boeoticum & Shi et al., 1998 \\
\hline Pm26 & $2 \mathrm{BS}$ & TTD140 & T. dicoccoides & Rong et al., 2000 \\
\hline$P m 27$ & $6 \mathrm{~B}-6 \mathrm{G}$ & $146-155-\mathrm{T}$ & T. timopheevii & Jarve et al., 2000 \\
\hline $\operatorname{Pm} 28$ & 1B & Meri & T. aestivum & Peusha et al., 2000 \\
\hline Pm29 & $7 \mathrm{DL}$ & Pova & A. ovata & Zeller et al., 2002 \\
\hline$P m 30$ & 5BS & $\mathrm{C} 20$ & T. dicoccoides & Liu et al., 2002 \\
\hline \begin{tabular}{|l|} 
Pm31(MIG) \\
cancel
\end{tabular} & $6 \mathrm{AL}$ & G-305-M/781//Jing411*3 & T. dicoccoides & Xie et al., 2003 \\
\hline$P m 32$ & 1BL.1SS & L501 & Ae. Speltoides & Hsam et al., 2003 \\
\hline$P m 33$ & $2 \mathrm{BL}$ & PS5 & T. carthlicum & Zhu et al., 2005 \\
\hline$P m 34$ & $5 \mathrm{DL}$ & NC97BGTD7 & Ae. Tauschii & Miranda et al., 2006 \\
\hline$P m 35$ & 5DL & NC96BGTD3 & Ae. Tauschii & Miranda et al., 2007 \\
\hline$P m 36$ & $5 \mathrm{BL}$ & MG29896 & T. dicoccoides & Blanco et al., 2008 \\
\hline$P m 37$ & $7 \mathrm{AL}$ & NC99BGTAG11 & T. timopheevii & Perugini et al., 2008 \\
\hline $\operatorname{Pm} 38$ & 7DS & RL6058 & T. aestivum & $\begin{array}{l}\text { Spielmeyer et al., } \\
2005\end{array}$ \\
\hline$P m 39$ & $1 \mathrm{BL}$ & Saar & T. aestivum & Lillemo et al., 2008 \\
\hline$P m 40$ & $7 \mathrm{BS}$ & GRY19 & Elytrigia intermedium & Luo et al., 2009 \\
\hline$P m 41$ & $3 \mathrm{BL}$ & IW2 & T. dicoccoides & Li et al., 2009 \\
\hline$p m 42$ & 2BS & G-303-1M & T. dicoccoides & Hua et al., 2009 \\
\hline$P m 43$ & $2 \mathrm{DL}$ & CH5025 & Thinopyrum intermedium & He et al., 2009 \\
\hline$P m 44$ & $3 \mathrm{AS}$ & Hombar & T. aestivum & Chen et al., 2011 \\
\hline $\operatorname{Pm} 45$ & $6 \mathrm{DS}$ & D57 & T. aestivum & Ma et al., 2011 \\
\hline
\end{tabular}


Table 2. Molecular markers linked to major powdery mildew resistance genes

\begin{tabular}{|c|c|c|c|c|c|c|}
\hline Gene & Location & $\begin{array}{l}\text { Type of } \\
\text { markers }\end{array}$ & Closest/flanking marker & $\begin{array}{c}\text { Linkage } \\
\text { distance/ } \\
\text { contribution }\end{array}$ & $\begin{array}{l}\text { Mapping } \\
\text { population }\end{array}$ & Reference \\
\hline \multirow[t]{4}{*}{ Pmla } & 7AL & RAPD, STS & UBC320420, UBC638550 & $\begin{array}{c}\text { Both } \\
\text { co-segregate }\end{array}$ & $\begin{array}{c}\mathrm{F}_{5}, \mathrm{~F}_{2} \text { lines } \\
\mathrm{BSA}\end{array}$ & Hu et al., 1997 \\
\hline & & RFLP & WHS178-9.4kb-EcoRI & $2.8 \pm 2.7 \mathrm{cM}$ & $\mathrm{F}_{2}$ lines,NILs & Hartl et al., 1995 \\
\hline & & RFLP & CDO347 & Co-segregate & $\mathrm{F}_{2}$ lines, NILs & Ma et al., 1994 \\
\hline & & RFLP, STS & $\begin{array}{c}\text { mwg2062, cdo347, psr121, } \\
\text { psr148, psr680, psr687, } \\
\text { wir148, C607, STS638542, } \\
\text { ksuh9 }\end{array}$ & $\begin{array}{c}\text { All } \\
\text { Co-segregate }\end{array}$ & $\mathrm{F}_{2}$ lines & Neu et al., 2002 \\
\hline \multirow[t]{3}{*}{ Pmlc } & 7AL & RFLP, RAPD & $\begin{array}{l}\text { WHS178-15kb-EcoRI, } \\
\text { OPH-111900 }\end{array}$ & $\begin{array}{c}4.4 \pm 3.6 \mathrm{cM} \\
13 \mathrm{cM}\end{array}$ & $\mathrm{F}_{2}$ lines, $\mathrm{BSA}$ & Hartl et al., 1995 \\
\hline & & AFLP & S19M22-325/200 & Co-segregate & $\begin{array}{c}\mathrm{F}_{3}+\mathrm{F}_{4} \text { lines } \\
\mathrm{BSA}\end{array}$ & Hartl et al., 1999 \\
\hline & & & S14M20-137/138 & Co-segregate & & \\
\hline Pmle & 7AL & SSR, AFLP & GWM344-null-S13M26-372 & $0.9 \mathrm{cM}, 0.2 \mathrm{cM}$ & $\mathrm{F}_{2: 3}$ lines, $\mathrm{BSA}$ & $\begin{array}{l}\text { Singrun et al., } \\
2003\end{array}$ \\
\hline \multirow[t]{3}{*}{$P m 2$} & $5 \mathrm{DS}$ & RFLP & $\begin{array}{c}\text { WHS350-6.5kb-EcoRV,WHS2 } \\
95\end{array}$ & $\begin{array}{c}3.8 \mathrm{cM}, 2.7 \pm 2.6 \\
\mathrm{cM}\end{array}$ & $\mathrm{F}_{2}$ lines, NILs & Hartl et al., 1995 \\
\hline & & RFLP & BCD1871 & $3.5 \mathrm{cM}$ & $\mathrm{F}_{2}$ lines, NILs & Ma et al., 1994 \\
\hline & & STS & STSwhs 350 & - & $\mathrm{F}_{2}$ lines, NILs & $\begin{array}{c}\text { Mohler \& } \\
\text { Jahoor, } 1996\end{array}$ \\
\hline$P m 3 a$ & $1 \mathrm{AS}$ & RFLP & WHS179 & $3.3 \pm 1.9 \mathrm{cM}$ & DH, NILs & Hartl et al., 1993b \\
\hline$P m 3 b$ & $1 \mathrm{AS}$ & RFLP & BCD1434 & $1.3 \mathrm{cM}$ & $\mathrm{F}_{2}$ lines, NILs & Ma et al., 1994 \\
\hline$P m 3 g$ & $1 \mathrm{AS}$ & RFLP & Gli-A5 & $5.2 \mathrm{cM}$ & $\mathrm{DH}$ & $\begin{array}{c}\text { Sourdille et al., } \\
1999\end{array}$ \\
\hline \multirow[t]{3}{*}{$P m 4 a$} & $2 \mathrm{AL}$ & RFLP & BCD1231, CDO678 & Co-segregate, & $\mathrm{F}_{2}$ lines, NILs & Ma et al., 1994 \\
\hline & & AFLP & 4aM1 & $3.5 \mathrm{cM}$ & $\begin{array}{c}\mathrm{F}_{3}+\mathrm{F}_{4} \text { lines } \\
\text { BSA }\end{array}$ & Hartl et al., 1999 \\
\hline & & STS & STSbcd1231-1.7kb & Co-segregate & NILs & Liu et al., 1998 \\
\hline Pm5e & $7 \mathrm{BL}$ & SSR & GWM1267-136 & $6.6 \mathrm{cM}$ & $\mathrm{F}_{2: 3}$ lines, $\mathrm{BSA}$ & $\begin{array}{l}\text { Huang et al., } \\
2003 \mathrm{a}\end{array}$ \\
\hline Pm6 & $2 \mathrm{BL}$ & RFLP & BCD135-9kb-EcoRV & $1.6 \pm 1.5 \mathrm{cM}$ & $\mathrm{F}_{2}$ lines, NILs & Tao et al., 2000 \\
\hline \multirow[t]{4}{*}{$\operatorname{Pm} 8$} & $1 \mathrm{RS} .1 \mathrm{BL}$ & RFLP & IAG95 & $\begin{array}{l}\text { Tightly } \\
\text { linkage }\end{array}$ & $\mathrm{F}_{2}$ lines, BSA & $\begin{array}{l}\text { Wricke et al., } \\
1996\end{array}$ \\
\hline & & RAPD & OPJ07-1200, OPR19-1350 & - & $\begin{array}{c}\text { Translocation } \\
\text { lines }\end{array}$ & \begin{tabular}{|c|} 
Iqbal \& Rayburn, \\
1995
\end{tabular} \\
\hline & & STS & SEC-1b-412bp & - & $\begin{array}{c}\text { Translocation } \\
\text { lines }\end{array}$ & $\begin{array}{l}\text { deFroidmont, } \\
1998\end{array}$ \\
\hline & & STS & STSiag95-1050 & Co-segregate & $\mathrm{DH}, \mathrm{F}_{2: 3}$ lines & $\begin{array}{l}\text { Mohler et al., } \\
2001\end{array}$ \\
\hline Pm12 & $\begin{array}{c}6 \mathrm{BS}-6 \mathrm{SS} \\
.6 \mathrm{SL}\end{array}$ & RFLP & $\begin{array}{c}\text { psr10, psr106, Nor-2, psr141, } \\
\text { psr113, psr142, psr149, psr2 }\end{array}$ & Co-segregate & $\mathrm{F}_{2}$ lines & Jia et al., 1996 \\
\hline$P m 13$ & 3BL.3SS & RFLP & psr305, psr1196 & - & Recombinant & Donini et al., 1995 \\
\hline
\end{tabular}




\begin{tabular}{|c|c|c|c|c|c|c|}
\hline Gene & Location & $\begin{array}{l}\text { Type of } \\
\text { markers }\end{array}$ & Closest/flanking marker & $\begin{array}{l}\text { Linkage } \\
\text { distance/ } \\
\text { contribution }\end{array}$ & $\begin{array}{l}\text { Mapping } \\
\text { population }\end{array}$ & Reference \\
\hline & \begin{tabular}{|c|}
$-3 \mathrm{~S}$ \\
$3 \mathrm{DL} .3 \mathrm{SS}$ \\
$-3 \mathrm{~S}$
\end{tabular} & & & & lines & \\
\hline & & $\begin{array}{l}\text { RFLP, RAPD, } \\
\text { STS }\end{array}$ & $\begin{array}{l}\text { cdo460, utv135, OPV13800, } \\
\text { UTV13, OPX12570, UTV14 }\end{array}$ & - & $\begin{array}{c}\text { Recombinant } \\
\text { lines }\end{array}$ & Cenci et al., 1999 \\
\hline Pm17 & $\begin{array}{c}\text { 1RS.1A } \\
\mathrm{L}\end{array}$ & RFLP, AFLP & IAG95-CA/CT-355 & $1.5 \mathrm{cM}$ & $\mathrm{F}_{2: 3}$ lines & Hsam et al., 2000 \\
\hline \multirow[t]{2}{*}{$\operatorname{Pm} 21$} & \begin{tabular}{|c|} 
6VS.6A \\
L
\end{tabular} & RAPD & OPH171900 & Co-segregate & $\mathrm{F}_{2}$ lines & Qi et al., 1996 \\
\hline & & RAPD, SCAR & $\begin{array}{l}\text { OPH171400, SCAR1265, } \\
\text { SCAR1400 }\end{array}$ & $\begin{array}{c}\text { All } \\
\text { co-segregate }\end{array}$ & $\mathrm{F}_{2}$ lines & Liu et al., 1999 \\
\hline \multirow[t]{2}{*}{$\operatorname{Pm} 24$} & 1DS & AFLP, SSR & E34/M51-407, Xgwm337-204 & $\begin{array}{c}\text { Co-segregate, } \\
2.4 \pm 1.2 \mathrm{cM}\end{array}$ & $\mathrm{F}_{2: 3}$ lines, $\mathrm{BSA}$ & $\begin{array}{l}\text { Huang et al., } \\
\text { 2000b }\end{array}$ \\
\hline & & SSR & Xgwm1291 & Co-segregate & $\mathrm{F}_{2: 3}$ lines & $\begin{array}{l}\text { Huang \& Roder, } \\
2003\end{array}$ \\
\hline $\operatorname{Pm} 25$ & $1 \mathrm{~A}$ & RAPD & OPA04950 & $12.8 \mathrm{cM}$ & $\begin{array}{c}\mathrm{BC}_{1} \mathrm{~F}_{1} \text { lines, } \\
\mathrm{BSA}\end{array}$ & Shi et al., 1998 \\
\hline Pm26 & $2 \mathrm{BS}$ & RFLP & wg516 & Co-segregate & RSLs & Rong et al., 2000 \\
\hline$P m 27$ & $6 \mathrm{~B}-6 \mathrm{G}$ & RFLP, SSR & psp3131 & Co-segregate & $\mathrm{F}_{2}$ lines & Jarve et al., 2000 \\
\hline $\operatorname{Pm} 29$ & 7DL & RFLP, AFLP & $\begin{array}{l}\text { S24M13-233, S19M23-240, } \\
\text { S22M26-192, S25M15-145, } \\
\text { S13M23-442, S22M21-217, } \\
\text { S17M25-226 }\end{array}$ & $\begin{array}{c}\text { Allco-segregat } \\
\mathrm{e}\end{array}$ & $\mathrm{F}_{2}$ lines, $\mathrm{BSA}$ & Zeller et al., 2002 \\
\hline Pm30 & $5 \mathrm{BS}$ & SSR & $\begin{array}{l}\text { Xgwm159-460, } \\
\text { Xgwm159-500 }\end{array}$ & $5-6 \mathrm{cM}$ & $\begin{array}{l}\mathrm{BC}_{2} \mathrm{~F}_{2} \text { lines, } \\
\text { BSA }\end{array}$ & Liu et al., 2002 \\
\hline Pm31 & $6 \mathrm{AL}$ & SSR & Xpsp3029 & $0.6 \mathrm{cM}$ & $\begin{array}{l}\mathrm{BC}_{2} \mathrm{~F}_{2} \text { lines, } \\
\text { BSA }\end{array}$ & Xie et al., 2003 \\
\hline Pm36 & $5 \mathrm{BL}$ & SSR & BJ261635 & Co-segregate & $\mathrm{BC}_{5} \mathrm{~F}_{5}$ & $\begin{array}{l}\text { Blanco et al., } \\
2008\end{array}$ \\
\hline$P m 40$ & $7 \mathrm{BS}$ & SSR & Xgwm297 & $0.4 \mathrm{cM}$ & $\mathrm{F}_{2}$ lines & Luo et al., 2009 \\
\hline Pm41 & $3 \mathrm{BL}$ & $\begin{array}{l}\text { SSR, ISBP, } \\
\text { STS }\end{array}$ & BE489472 & Co-segregate & $\mathrm{F}_{2}$ lines & Li et al. (2009) \\
\hline Pm42 & $2 \mathrm{BS}$ & $\begin{array}{l}\text { SSR, } \\
\text { FLP-SCAR, } \\
\text { EST-STS, } \\
\text { RFLP-STS }\end{array}$ & BF146221 & Co-segregate & $\mathrm{F}_{2}$ lines & Hua et al., 2009 \\
\hline Pm43 & $2 \mathrm{DL}$ & SSR & Xwmc41 & $2.3 \mathrm{cM}$ & $\begin{array}{l}\mathrm{F}_{3} \text { and } \mathrm{BC}_{1} \\
\text { lines }\end{array}$ & He et al., 2009 \\
\hline$P m 45$ & $6 \mathrm{DS}$ & SSR, STS & Xmag6176 & $2.8 \mathrm{cM}$ & $\mathrm{F}_{2}$ lines & Ma et al., 2011 \\
\hline
\end{tabular}


Table 3. Distribution of powdery mildew resistance genes among homoelogous chromosomes in wheat and Rye

\begin{tabular}{|c|c|c|c|c|}
\hline $\begin{array}{c}\text { Homoelogous } \\
\text { group }\end{array}$ & $\mathrm{A}$ & $\mathrm{B}$ & $\mathrm{D}$ & $\mathrm{R}$ \\
\hline 1 & $P m 3, P m 25$ & $P m 28, P m 32$ & $P m 10, P m 24$ & $P m 8, P m 17$ \\
\hline 2 & $P m 4, P m 23$ & $P m 6, P m 26, P m 33, p m 42$ & $P m 43$ & $P m 7$ \\
\hline 3 & $P m 44$ & $P m 13, P m 38, P m 41$ & & \\
\hline 4 & $P m 16$ & & & $P m 20$ \\
\hline 5 & $P m 21, P m 31$ & $P m 11, P m 12, P m 14$, & $P m 45$ & \\
\hline 6 & $P m 1, P m 9, P m 18$, & $P m 37, P m 35$ & \\
\hline 7 & $P m 37$ & $P m 5, P m 40$ & $P m 15, P m 19, P m 29, P m 39$ & \\
\hline
\end{tabular}

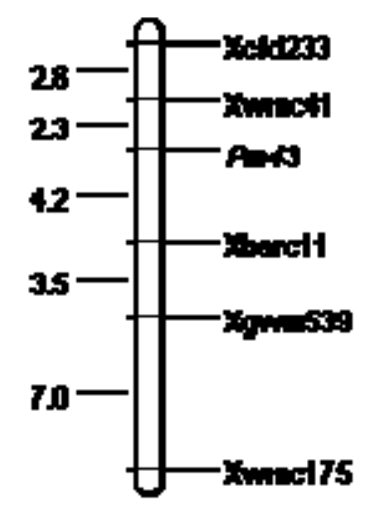

$2 \mathrm{DL}$

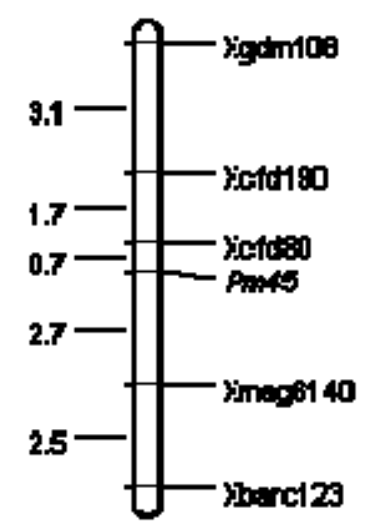

$6 \mathrm{DS}$
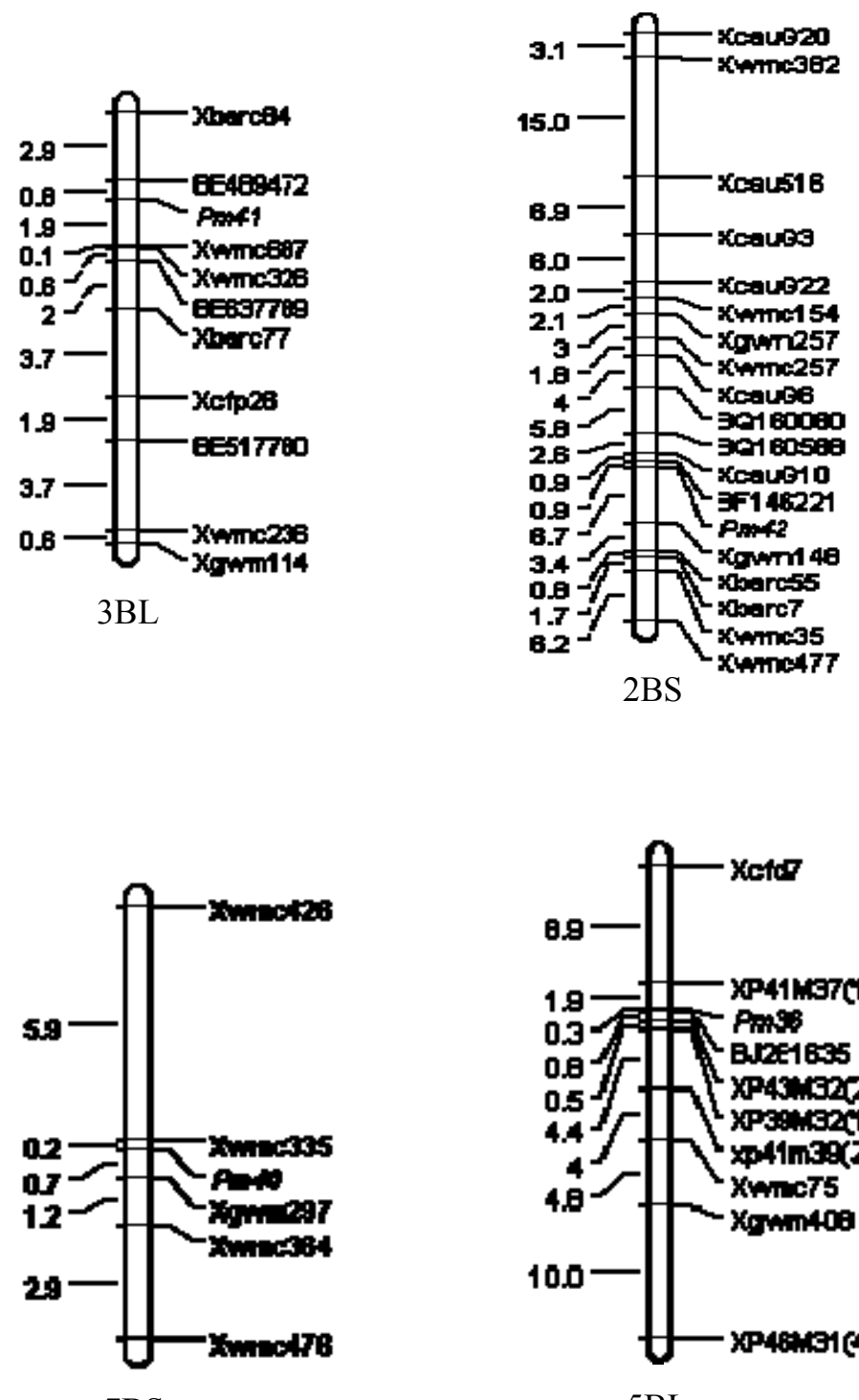

$7 \mathrm{BS}$

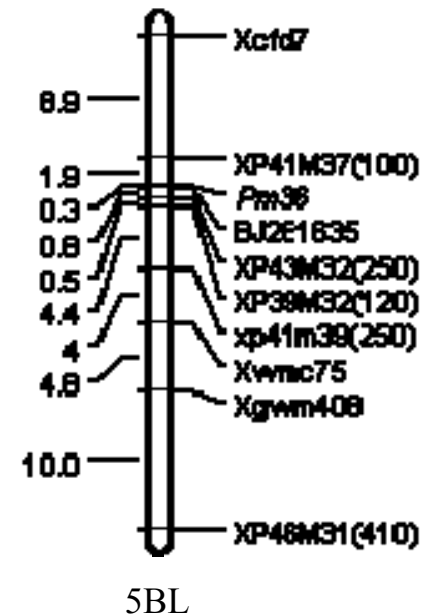

$5 \mathrm{BL}$

Figure 1. Genetic linkage maps of powdery mildew resistance gene- Pm43 (He et al., 2009), Pm41 (Li et al. 2009), pm42 (Hua et al., 2009), Pm45 (Ma et al., 2011), Pm40 (Luo et al., 2009) and Pm36 (Blanco et al., 2008) 